OPEN ACCESS

Edited by:

Virginia Barba-Sánchez, Universidad de Castilla-La Mancha

Spain

Reviewed by:

Silvio Manuel da Rocha Brito, Instituto Politécnico de Tomar (IPT),

Portugal

David Padilla-Gongora,

University of Almeria, Spain

*Correspondence:

Tancredi Pascucci

tancredipascucci@usal.es

Specialty section:

This article was submitted to

Organizational Psychology,

a section of the journal

Frontiers in Psychology

Received: 08 July 2021

Accepted: 09 November 2021

Published: 06 January 2022

Citation:

Pascucci T, Cardella GM

Hernández-Sánchez B and

Sánchez-García JC (2022) Systematic

Review of Socio-Emotional Values

Within Organizations.

Front. Psychol. 12:738203.

doi: 10.3389/fpsyg.2021.738203

\section{Systematic Review of Socio-Emotional Values Within Organizations}

\author{
Tancredi Pascucci*, Giuseppina Maria Cardella, Brizeida Hernández-Sánchez and \\ Jose C. Sánchez-García
}

Cátedra de Emprendedores, Universidad de Salamanca, Salamanca, Spain

The theory of separation assumes, with provocation, that an organization cannot reconcile profits and social function. Organizations can reconcile these two, apparently contrasting, missions, by considering emotions, especially moral emotions, to create a genuine motivation for focusing on goals beyond simple economic earnings and protecting organizations or groups of people from dysfunctional attitudes and behaviors, as well as considering the important role of the stakeholder accountability. Using the PRISMA method, we created a review of records using keywords relating to a socioemotional value within organizations, with a particular focus on the last 20 years. We used the SCOPUS database and, after removing irrelevant records, we used the VOSviewer tool to create a cluster map of different areas in this topic. Some records cite the socio-emotional value that is related to organizational and employee suffering, while other articles consider it a positive factor that improves performance and prevents problems in organizations.

Keywords: organization, emotion, social, value, socio-emotional influence, stakeholder

\section{INTRODUCTION}

Entrepreneurial organizations are structures that develop ideas from all members, promoting alternative views and projects (Burger-Helmchen, 2013). Their social function aims to facilitate cohesion between people, institutions, and a collective conscience (Barbaro, 2008). For the theory of separation (Friedman, 1962; Werhane and Freeman, 1999; Alzola, 2011), social function and profits are two separate and independent missions of an entrepreneurial organization. Many authors have attempted to reconcile this dualism through research (Freeman, 2000; Freeman et al., 2004; Wempe, 2008; Hartman, 2011). The theory of separation follows an ideological dualism, whereby the entrepreneurial world (Thorpe et al., 2006), based on profit and with an individual mode, fights against a collective strategy, which aims to achieve a common good and neglects earnings. Recently, however, there has been a change due, in part, to overcome the ideological contraposition that preceded the fall of the Berlin Wall and the collapse of many state-run enterprises (YanishevNesterova, 2020), when it became necessary to create a new entrepreneurial paradigm that united the entrepreneurial efficiency with a sensitivity to social, ecological, and community areas (Magala, 2002). Even before the fall of Communism, there was debate over whether an extremist approach of maximum vs. minimal state intervention was sufficient for finding a solution for the economy in some countries (Valaskakis, 1987), suggesting a strategy, in which, state institutions form partnerships with the entrepreneurial world to tackle certain problems. Social entrepreneurship is 
not a recent topic, having been studied since the 1970s (Moran, 1976), not only in authoritarian countries, where there is a need for the state to perform social functions to reach consensus (Tuber, 2019) but also in democratic and liberal countries, following a research path that can be considered parallel to studies about the classic entrepreneurial paradigm. In this case, there is an unavoidable need to reconcile a social mission with an earnings goal, which can be realized through rational resource management. Emotions (Graca, 2017) and moral emotions are important for giving information that could not be delivered through simple, rational, and emotionally deprived thinking, not only for an insufficient perception of reality (Miceli and Castelfranchi, 2018) but also to help us perceive the suffering and disagreement of others, to improve their lives, and to avoid anger, sadness, anxiety, and negative behavioral consequences, thereby preventing aggressive acts (Caprara et al., 2014). The quest to overcome the past division between emotions and rationality began with the ancient Greek dualism of "pathos" and "logos" and continued throughout the subsequent centuries. This contraposition was eliminated by the psychoanalytic approach (Freud, 1911; Rayner, 1995; Blanco, 2019), whereby the human mind is shown to work without following a rational line, using cognitive sciences (Beck, 1967; Arnold, 1984), in which emotion, rational processes, and cognitive functions are melted down to give us the opportunity to evaluate and manage our daily lives using the emotive intelligence paradigm (Goleman, 1996), which states that even people with the highest scores on the traditional intelligence quotient (IQ) test can perform worse than people with lower IQs but higher emotional intelligence. Emotions are important during strategic phases of organizational life, such as succession (Manzoor et al., 2018), especially in a family firm (Razzak et al., 2019). Emotions are important for reinforcing our moral and social motivations, which propel our actions toward reaching a less selfish goal that is more oriented toward equity and justice ideals. An important position in this paradigm is the stakeholder, a person or group interested in pursuing specific goals - in this case, also oriented toward social responsibility - within an organization (McVea and Freeman, 2003; Verkerk, 2013; Correa and Larringa, 2015; Barrena Martinez et al., 2016; Elizandro et al., 2018) in the areas of sport (Escamilla-Fajardo et al., 2020), education (Tolochko et al., 2020), environment (Lawrence et al., 2020), engineering (Cierna and Sujova, 2020), or medicine (Blau et al., 2012; Lierville et al., 2015; Stawicki and Firstenberg, 2018; Lomakina, 2020; Naslund, 2020).

There is a dualistic conception: An organization with a "pure" entrepreneurial philosophy, founded on profit and an individualistic view based on a zero-sum-game, where the profits of an organization are more important than the richness and wellness of society; in contrast, there is an organization that adopts a strategy strictly oriented to improving society, in terms of health, security, quality of life, or other aspects, without consideration for profit, resulting in a poor or sometimes negative economic balance (Nikodemska-Wolowik, 2008; Kirzner, 2019; Mensik, 2019). The social accounting for the stakeholder model is a paradigm, where even an entrepreneurial organization that is usually focused on satisfying only the interests of its founders and shareholders must also consider the needs of the society and the community in which it operates (Hadden, 2012; Tang and Luo, 2016; Bhatia et al., 2020; Dimitropoulos, 2020). While a traditional entrepreneurial approach involves capital investment by one person, two or more associates, or a total or prevailing state capital, there has recently appeared a new form of capital contribution, crowdfunding (Pavlidou et al., 2020). This is a solid alternative to these strategies because institutional resources are often delayed by bureaucratic procedures, while spontaneous fundraising by a private organization depends on the individual willingness of organizational associates. This strategy, which is more efficient, has been used in different areas, such as social entrepreneurship (Morell et al., 2020; Figueroa-Armijos and Berns, 2021; Motero et al., 2021), research (Dalrup et al., 2020), and start-up development (Lee and Lehdonvirta, 2020; Shi et al., 2021), to help different small investors support international entrepreneurial activity (Tiberius and Hauptmeijer, 2021) or cope with international crises, due to ecologic emergencies (Predkiewcz and Kalinowska-Beszczynska, 2020) or pandemics (Saleh et al., 2021). Previously, these areas could be treated in a sufficiently short time because, while public institutions are dedicated to managing problems that are potentially harmful to the community, they are sometimes limited by bureaucracy, political dynamics, priorities on interventions, and temporary or permanent lack of resources; meanwhile, private organizations have difficulty managing some national crises that make it necessary to switch from a profit-making to a social mindset. This difficulty emerged clearly during the coronavirus disease 2019 (COVID-19) pandemic that started in 2020 when both liberal and centralized systems faced important difficulties for the aforementioned reasons, including liberal countries with a profit-making philosophy, delayed lockdowns, and antiepidemic measures to save money and economic activities; in contrast, governments that put the wellness of people first had important difficulties for a more complex reason, that is, people in this situation were considered more important than the economy, but many workers suffered from the pause in economic activities, while many citizens also suffered a perceived loss of freedom to move due to lockdowns imposed in different countries around the world. This situation made politicians respond to different requests from people, with demands to guarantee health but also work rights, which are irreconcilable aspects; whoever has to state a priority between these two functions suffers a sort of "double bind," risking the loss of political appreciation by choosing one over the other. Organizations must consider socioemotional aspects without focusing only on profit-making goals and considering their social function, based on a genuine and sincere motivation, without following a consensus approach that is typically adopted by political leaders or parties, who change their priorities to maintain power (Gellatelly and Kiernan, 2003).

\section{MATERIALS AND METHODS}

We believe that socio-emotional factors are not just for consideration in clinical studies as a psychological weakness that needs to be cured but also in a positive way, as psychological 
wellbeing indicators or protective factors within organizational studies. Our hypotheses can be summarized as follows:

1. During the last 20 years, articles discussing the importance of socio-emotional factors have significantly increased.

2. Socio-emotional factors are not only considered negative, for example, appearing in clinical studies.

3. Socio-emotional influence is considered to be a positive factor in improving organizational management.

In this study, we considered the influence of socio-emotional factors on the life of organizations, considering both negative consequences, where a "suffering" organization is characterized by negative emotions among its members, studying its normal working and functioning considering a normal socio-emotional process, or considering records mentioning organizational strategies based on the socio-emotional aspects. We used the PRISMA statement (Liberati et al., 2009) to refine our research, using SCOPUS to obtain a literature review about this phenomenon, without considering the publication year 2021 and considering all records marked as articles or reviews, excluding conference articles, conference reviews, editorials, letters, notes, short surveys, erratum, books, and book chapters. We used a Boolean String "ORGANIZATION" AND "EMOTIONAL VALUE" OR "SOCIAL VALUE" and excluded all pertinent records regarding non-psychological or organizational business areas. We considered only records with the following inclusion criteria:

1. Records discussing both lucrative and nonlucrative organizations.

2. Records discussing entrepreneurial organizations.

3. Records discussing organizations belonging to public institutions.

4. Records written in English.

We also stated exclusion criteria and did not consider records defined by the below keywords within their subject area because they did not involve a psychological aspect:

- Biochemistry

- Medicine

- Mathematics

- Earth Sciences

- Physics

Once we refined a list of records on SCOPUS, we used VOSviewer (Waltman et al., 2010) to create a cluster analysis using author keywords and excluding redundant keywords, reusing SCOPUS to cite them within each cluster.

\section{RESULTS}

We extrapolated 1,761 records. The first mention citing the influence of socio-emotional value on organizations appears in a publication of 1922 (Link, 1922), describing a Psychological Service Centre, where, despite strong stress on individual psychology among first clinical psychological contributions, there is a significant sensibility about organizational functioning, going beyond simple individual psychology. After this first work, there were no further articles for almost 20 years, with some articles after the 1960s about therapeutic groups and health organizations. If we consider the number of records during each decade between the 1960s and the 2020s, as we can observe in Table 1, we notice an exponential incrementation of studies about this area, with more than 50 articles published by the 1990s. We hypothesized that the importance of socio-emotional influence on organizations is due to the birth of interest in emotions (Burton, 1963; Krebs, 1975; Hoppe, 1983; Goodnow, 1990) outside clinical and experimental psychology, which, up to the second half of the twentieth century, were exclusively treated within psychotherapy studies and laboratory walls.

Continuing to represent a graphical trend in Figure 1, we revealed that this trend has grown over the last 20 years, with a vail between 2005 and 2010 (probably due to the important economic crisis during 2007-2009) and a good incrementation after 2015.

If we consider countries that have published at least 30 records about this topic, we can observe in Figure 2 that the United States is the highest publishing country, with a significant gap to others. The United States, the United Kingdom, and Australia are the first three countries treating this topic, showing the supremacy of an Anglo-Saxon research approach, even though many Asian and European countries contribute.

Considering most active journals as presented in Tables 2, 3, we underline how much socio-emotional value is a core topic in most business management publications, where the organization has to consider the variables in order to have a peculiar sensitivity to satisfying community requests and to preserve a positive organizational climate and individual wellness among personnel. Some journals in this area have an h-index superior to 40 , showing how much this area attracts important research teams.

Despite the Anglo-Saxon supremacy of the literature, if we consider the most productive authors, there are many contributions from Spanish, Turkish, Israeli, and Indian researchers. The most prolific author on this list is Applebaun from a Business School in Montreal, who has written articles about leadership and stereotypes among organizations (Applebaun et al., 2016c). Emotional intelligence is an important area of interest for various authors (Boyatzis, 2009; Boyatzis and Ratti, 2009; Gabel-Shemueli and Dolan, 2011; Meisler, 2014): Eisenberger, affiliated with the Psychology Department in Houston, focuses on organizational perceived support, another important aspect in the wellbeing of employees (Ameli et al., 1998; Kim et al., 2016; Kurtessis et al., 2017), and Karatepe and Srivastava are Turkish and Indian researchers, respectively, who publish articles about negative socio-emotional aspects

TABLE 1 | Number of records for each decade with more of 50 records publication and incrementation publishing rate.

\begin{tabular}{lcc}
\hline Publishing years & Records No. & \% Incrementation rate \\
\hline $1991-2000$ & 103 & $110 \%$ \\
$2001-2010$ & 403 & $289 \%$ \\
$2011-2020$ & 1201 & $202 \%$
\end{tabular}




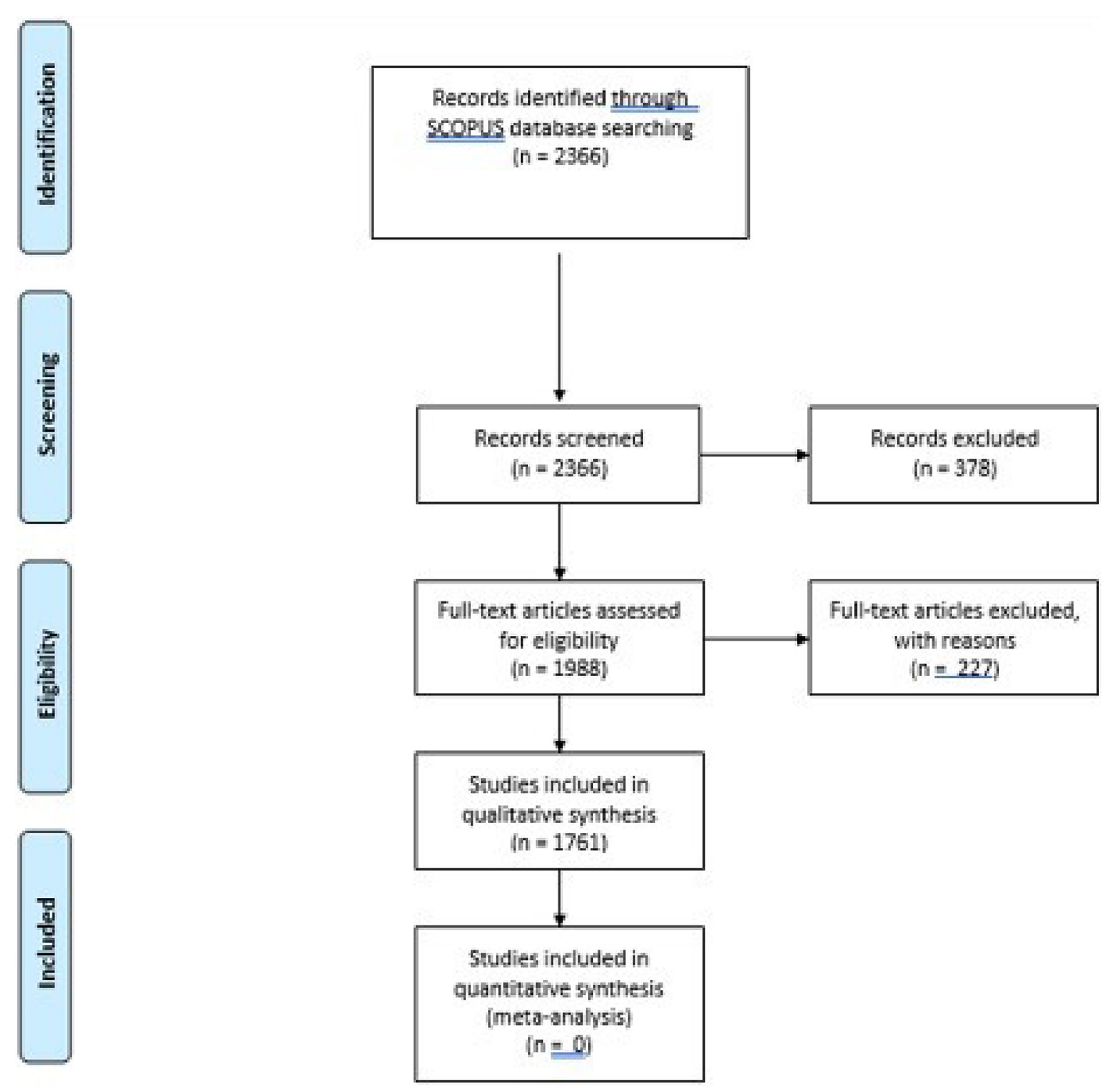

FIGURE 1 | Graphical representation of records number during last 20 years.

regarding organizations, such as burnout or work-family conflict (Karatepe and Tekinus, 2006; Karatepe and Zargar-Tizabi, 2011; Karatepe, 2015; Srivastava et al., 2019; Srivastava and Argawal, 2020; Srivastava and Dey, 2020).

We used VOSviewer to divide the previous group of articles on SCOPUS, using their author keyword co-occurrence. We stated a minimum of 10 occurrences, extrapolating 53 items. We revealed a graphical representation, which was regrouped into six different clusters. These clusters, with their co-occurrence, are graphically represented in another image in Figure 3.

\section{Cluster (Red Colored) 1: Emotional Exhaustion (15 Items, 318 Records)}

This is the cluster regrouping with the highest record number (18\% prevalence) and recalls significant distress within organizations (Peng et al., 2010; Reed et al., 2018), regarding both users and personnel, where the psychological suffering of the first damages the second and vice versa. Stress (Deckard and Present, 1989; Micael et al., 2008; Richardsson et al., 2008; Martinèz et al., 2013; Sheldon et al., 2015; Linden et al., 2018; Prada-Ospina, 2019), anxiety (Goetz et al., 2006; MacNeil et al., 2009; Inal et al., 2010; Shongwe and Cilliers, 2020; Wu et al., 2020), and depression (LeDoux et al., 1998; Galvin et al., 2006; Jafri et al., 2011; Karatepe and Zargar-Tizabi, 2011; Rooney and Grant, 2013; Wu et al., 2020) are principal indicators of this psychological symptomatology, sometimes reaching dangerous levels and becoming a psychiatric emergency (Johnson et al., 2016; GilRivas et al., 2019). This vulnerability makes personnel members uncomfortable, causing burnout (Booth and Faulkner, 1986; Gupchup et al., 1994; Robinson et al., 2003; Skaalvik and Skaalvik, 2011; Rama-Maceiras et al., 2012; Glaser and Hect, 2013; Huynh et al., 2014; Malik et al., 2016), which has important consequences not only at the individual level but also 


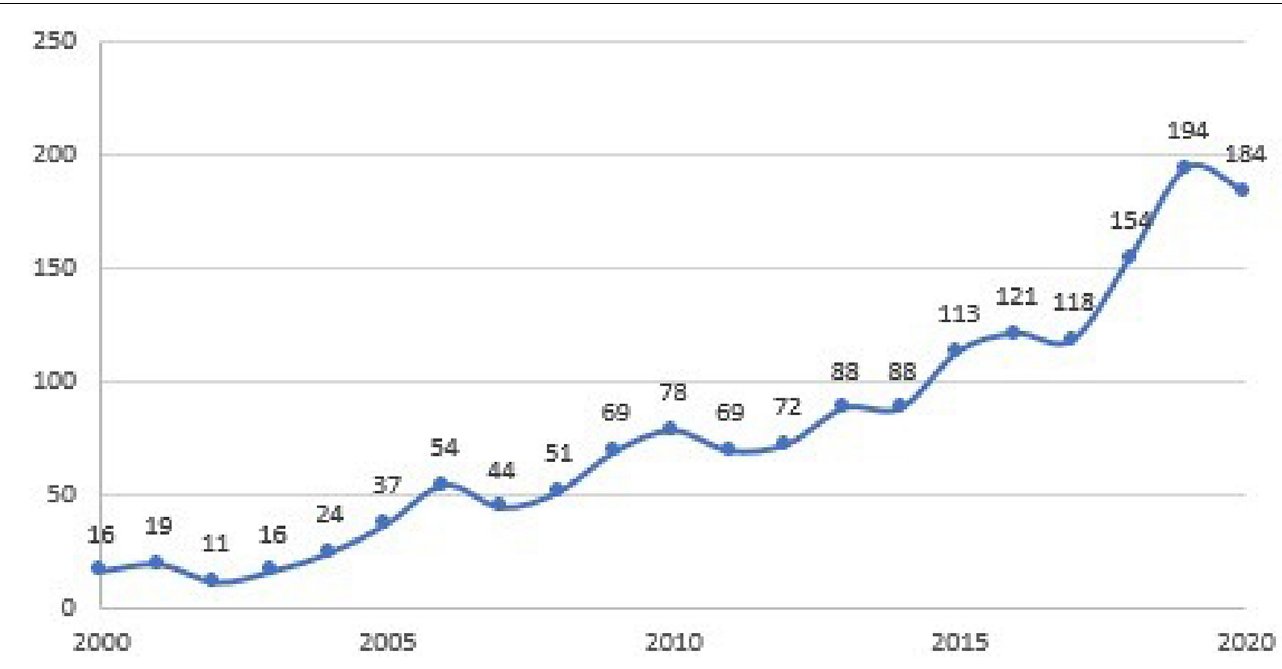

FIGURE 2 | Graphical representation of most active publishing countries.

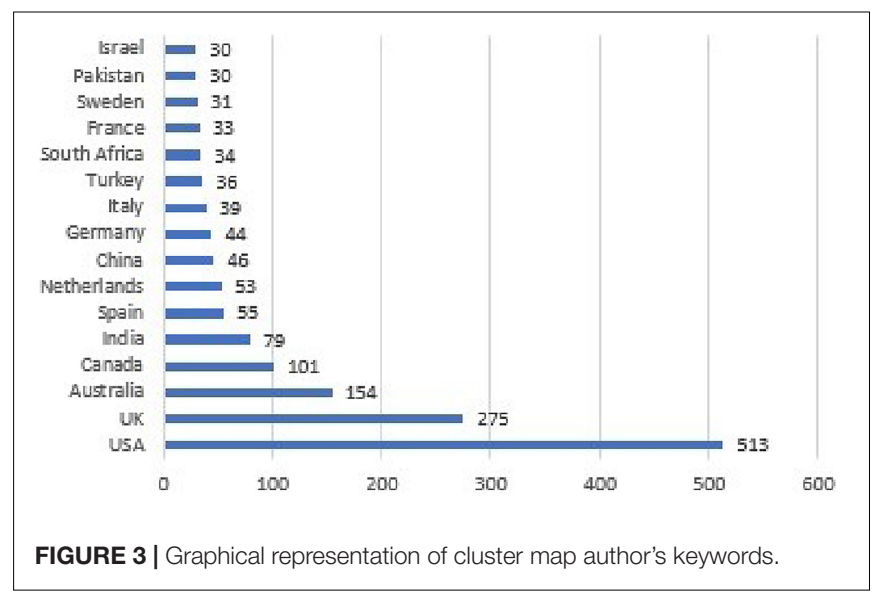

to family and working performance (Glaser and Hect, 2013; Babic et al., 2020).

\section{Cluster (Green Colored) 2: Emotional Intelligence (12 Items, 297 Records)}

This cluster is the second most numerous cluster $(17 \%$ prevalence) regarding socio-emotional aspects (Crusheil, 2006; Kerr et al., 2006; Akerjordet and Severinsson, 2007; Hopkins et al., 2007; Koman and Wolff, 2008; Coskun et al., 2018; Chen et al., 2019; Perez-Fuentes et al., 2019), which can create a buffer effect against distress within organizations, preventing individual and organizational suffering. Organizations are not purely rational institutions (Carter, 2005) where every individual has a precise role, with tasks to perform and intervention protocols to manage automatically with plenty of clear satisfaction and without ambiguities and inner conflicts (Chiva and Alegre, 2008; Meisler, 2014). People who work are not always satisfied with their personal and working life and clearly change jobs constantly. They are sometimes frustrated by difficulties, and working skills cannot be evaluated, excluding emotional components. Emotional intelligence (Chrusciel, 2006; Suliman and Al-Shaikh, 2007; Davies et al., 2010), since its introduction by Goleman (1996), defines an important ability to cope with problems that cannot be navigated using only intellectual skills (Brown et al., 2006), considering also moral aspects that a pure rational intelligence does not consider, thereby creating learning opportunities (McCracken, 2005; Vorhauser-Smith, 2011; Starbuck, 2017). Emotional intelligence can be used within organizations to prevent emotional exhaustion (Meisler, 2014; Clark and Polesello, 2017), to manage and create an appropriate organizational climate (Der Foo et al., 2004; Morehouse, 2007; Chen et al., 2016) that improves organizational performance (Gabel-Shemueli and Dolan, 2011; Wei and Li, 2011; BettisOutland and Guillory, 2018) and leadership (Kent, 2006; Fowlie and Wood, 2009; Hess and Bacigalupo, 2010; Lindebaum and Cartwright, 2011; Applebaun et al., 2016a,b,c,d) and provides organizations with an ethical approach (Rok, 2009; Fairchild, 2010; Capell and Gabell-Shemueli, 2013; Caldwell and Hayes, 2016; Asgary and Lawrence, 2020).

\section{Cluster (Blue Colored) 3: Organizational Culture and Knowledge Sharing (8 Items, 89 Records)}

An important aspect of organizations is the cooperation between different workers within their organization (Shihi and Susanto, 2010). This aspect, apparently simple and reasonable, is sometimes forbidden, bringing the workers of an organization to work without coordination (Cangemi et al., 2008; Daniels, 2009; Kahili, 2017). This means that different departments or workers from the same organization could work on the same task doing intervention already carried out by the other (Meisler and Vigoda Gadot, 2014), or sometimes performing counterproductive actions (Zhang and Shi, 2017), just like a psychiatrist who prescribes psychotropic drugs with significant collateral effects for a cardiopathic patient cured by another physician. Organizations have their peculiar organizational 


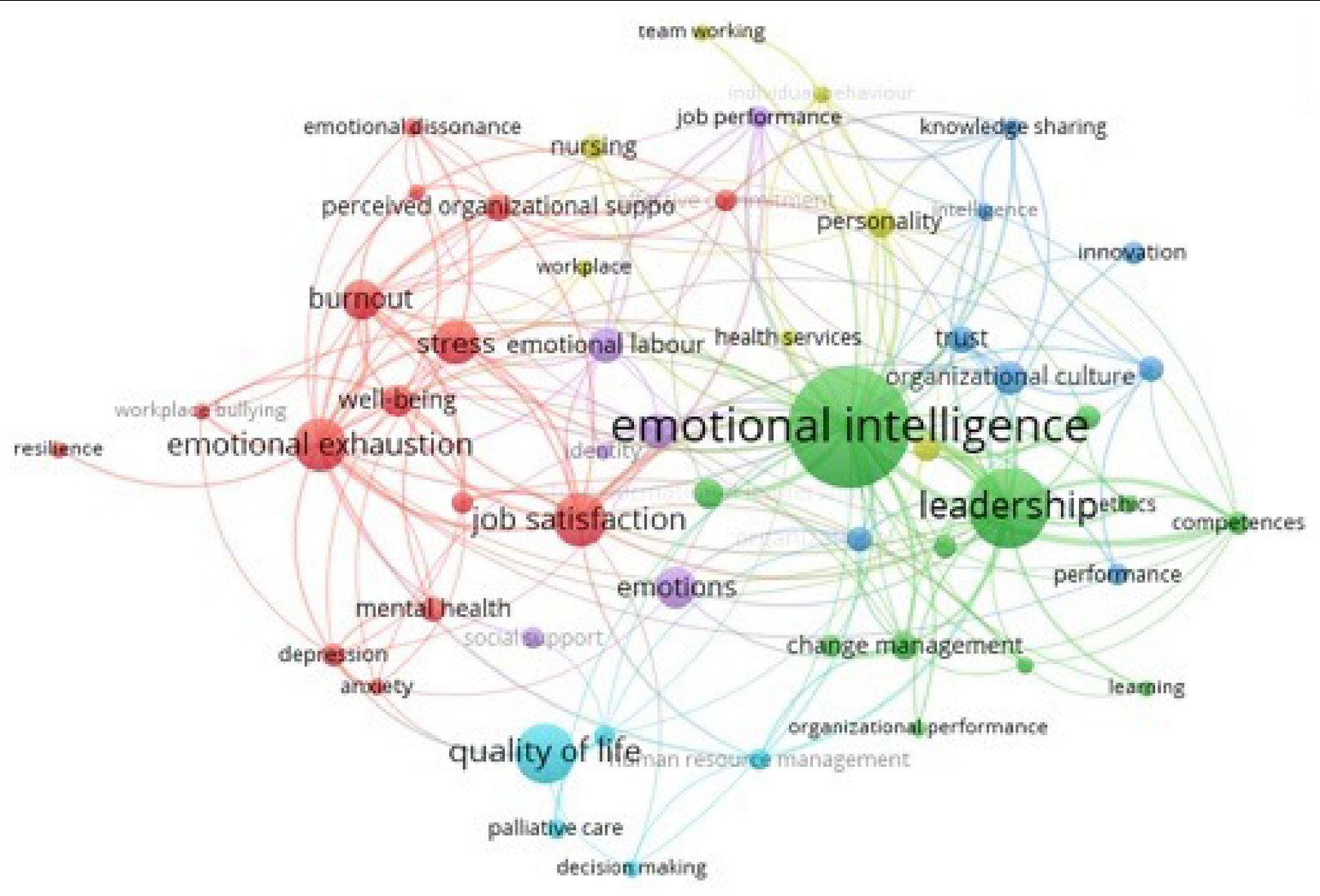

FIGURE 4 | PRISMA statement about socioemotional values in organizations.

climate (Armeli et al., 1998; Worthington, 2012), their myths (Gordon and Winpenny, 1996; Bao et al., 2013), their mission and objective (Campbell and Yeung, 1991; Rahmani et al., 2015; Krajcsàk, 2018; Serwint and Stewart, 2019), group resilience, and power (Freeman and Carson, 2006; Leggat and Balding, 2013; Seyedpour et al., 2020), where the individuality of every single worker should be directed at the same goal (Flanagan and Henry, 1994; Leggat and Balding, 2013; Gokturk et al., 2017; Herkes et al., 2019). Better cooperation and communication are important for trust between different workers (Dibben, 2004; Swift and Hwang, 2013; Lim et al., 2018), which grants better cooperation and knowledge sharing, preventing useless or chaotic actions.

\section{Cluster (Yellow Colored) 4: Care Services Communications (7 Items, 175 Records)}

Some organizations and professions have a superior emotional investment (Penticuff, 1989; Ho, 2007; Hujala and Rissanen, 2011) than those in which the professional has to stress less about the rational and technical aspects of their activities. A classic example is the helping professions, where helpers have scientific protocol interventions to use but cannot exclusively manage their job without considering socio-emotional aspects (Ramo et al., 2009; Fairchild, 2010). Nurses (Severinsson and Hallberg, 1996; Tuck and Wallace, 2000; Wright and Baker, 2005; Evans, 2006; Stone et al., 2006; Strandas et al., 2019) are typically one of the principal professions dedicated to superior socioemotional nearness to patients (Brunton, 2005; Waddington and Fletcher, 2005; Ostaszkiewicz et al., 2016). If we compare their relationship with a more detached physician-patient relationship (Dubler, 1995), they are the principal person who constantly manages the illness of a patient, even more than a parent or other sanitarian workers. Considering that, socio-emotional influence is not only fundamental to preventing a psychological collapse in these cases but also to improving caregiver-patient relations and communication (Thomson and Hecker, 2001; Loosemore, 2010; Vinall-Collier et al., 2016), with a positive effect on the healing process (Rustoen, 1998; Molter, 2003). This interaction is a result of two personalities of the patient-nurse dyad, comprehending both normal and sometimes pathological but functional personalities (Dijkstra et al., 2005; Young and Dulewitz, 2007; Igarashi et al., 2009; Wolff and Kim, 2012; Lounsbury et al., 2016; Schwarz et al., 2016).

\section{Cluster (Violet Colored) 5: Gender Issue (6 Items, 250 Records)}

Female workers are considered more oriented to emotions than men; it is the third most representative cluster (i.e., $14 \%$ prevalence), and female workers are typically involved in some working activities, such as nursing (Severinsson and Hallberg, 1996; Tuck and Wallace, 2000; Wright and Baker, 
TABLE 2 | List of most active journals about this research line.

\begin{tabular}{|c|c|c|c|}
\hline No. & Journals & h-index & Research area \\
\hline 32 & Journal of Management Development & 55 & $\begin{array}{l}\text { Business and Management Accounting; Organizational Behavior } \\
\text { and Human Resource Management }\end{array}$ \\
\hline 30 & Journal of Organizational Change Management & 66 & Business, Management Accounting; Decision Sciences \\
\hline 29 & Journal of Managerial Psychology & 74 & $\begin{array}{l}\text { Business, Management Accounting; Decision Sciences, } \\
\text { Psychology }\end{array}$ \\
\hline 29 & Personnel Review & 67 & Business Management Accounting; Psychology \\
\hline 26 & Leadership and Organization Development Journal & 62 & $\begin{array}{l}\text { Business, Management and Accounting; Organizational behavior } \\
\text { and Human resource management }\end{array}$ \\
\hline 18 & Journal of Services Marketing & 96 & Business, management and accounting \\
\hline 16 & Employee relations & 48 & $\begin{array}{l}\text { Business, management and accounting; Organizational Behavior } \\
\text { and Resource Management }\end{array}$ \\
\hline 15 & Human Resource Management International Digest & 11 & Organizational Behavior and Resource Management \\
\hline 15 & International Journal of Conflict Management & 50 & Business, management and accounting; Social Sciences \\
\hline 15 & Management Decision & 91 & Business, management and accounting; Decision Science \\
\hline
\end{tabular}

TABLE 3 | List of authors with more of 4 publications about socio emotional influence.

\begin{tabular}{|c|c|c|c|c|}
\hline No. & Author & Affiliation & h-index & Prevailing research area \\
\hline 5 & Applebaun, S., H. & John Molson School of Business, Montreal, Canada & 27 & $\begin{array}{l}\text { Business Management Accounting; Social Sciences; Decision } \\
\text { Sciences. }\end{array}$ \\
\hline 4 & Boyatzis, R., E. & Cleveland University, United States & 31 & $\begin{array}{l}\text { Business Management Accounting; Psychology; Social Sciences; } \\
\text { Economics, Econometrics. }\end{array}$ \\
\hline 4 & Dolan, S., L. & ESADE, Barcelona, Spain & 12 & $\begin{array}{l}\text { Business Management Accounting; Psychology; Social Sciences; } \\
\text { Medicine; Economics, Econometrics. }\end{array}$ \\
\hline 4 & Eisenberger, R. & University of Houston, United States & 40 & $\begin{array}{l}\text { Psychology; Social Sciences; Business Management Accounting; } \\
\text { Medicine. }\end{array}$ \\
\hline 4 & Karatepe, O., M. & Mersin University, Turkey & 44 & $\begin{array}{l}\text { Business Management Accounting; Social Sciences; Economics, } \\
\text { Econometrics and Finance; Environmental Sciences }\end{array}$ \\
\hline 4 & Mesler, G. & Haifa University, Israel & 6 & $\begin{array}{l}\text { Business Management Accounting; Psychology; Economy, } \\
\text { Econometrics; Social Sciences; Medicine. }\end{array}$ \\
\hline 4 & Srivastava, S. & Jaipur Institute of Management, Noida, India & 4 & $\begin{array}{l}\text { Business Management Accounting; Social Sciences; Economy, } \\
\text { Econometrics; Decision Sciences; Psychology. }\end{array}$ \\
\hline
\end{tabular}

2005; Evans, 2006; Stone et al., 2006; Gray, 2009; Strandas et al., 2019) and school education (Salami, 2008; Galtseva et al., 2020). Some of these activities are more complicated than others and sometimes less socially considered (Syed et al., 2005; Gray, 2009, 2010; Blau et al., 2012; Yagil, 2014; Hur et al., 2015; Shin et al., 2015; Pandley, 2018; Adams and Mastracci, 2020; Dhliwayo and Coetze, 2020). This cluster focuses on both positive and negative emotions (Donnay et al., 1993; Wilkinson, 2002; Humphreys et al., 2005; Driller et al., 2011; Mularz and Johansen, 2016).

\section{Cluster (Light Blue Colored) 6: Hospital and Quality of Life (5 Items, 207 Records)}

This cluster is located within the walls of the hospital and is treated by intervention protocols based on the socio-emotional influence (Berman et al., 2016). Hospital patients cannot be cured using only medication and pharmacological therapies and must be considered as human beings with their own personalities and desires, needs, and fears. Medicine must consider life wellness and satisfaction in patients, especially for medical pathology, where psycho-social aspects and quality of life of patients
(Powell and Kornfeld, 1993; Knight et al., 2001; Erim et al., 2015) contribute to a better disease progression, considering the severity of their clinical condition, which can be chronic, mild, or permanent (Duncan and Siegal, 1998; Sengelov et al., 2000; Tsunoda et al., 2007; Segalla et al., 2008; Inal et al., 2010; Yu et al., 2010). Palliative therapies in this case, sometimes have significant prognostic effectiveness despite usually being used in terminalillness departments, and the decision-making process (Solloway et al., 2005; Oliver and Jacobs, 2007; Gronstad, 2017; Bakst et al., 2019) during therapy is a fundamental aspect in diagnosing and acting at the right moment during the healing process.

\section{DISCUSSION}

This study did not only consider emotional (Lombard, 2021) or social (Micaelson, 2021) values because these constructs are often used interchangeably, even if there are some important differences. In contrast to the "hard" sciences, we treated a research area full of disturbing variables as decision science, where we must adopt a complexity paradigm (Jorm et al., 
2021). Considering a negative attitude through socio-emotional influence, people who use an emotional approach are irrational and potentially target manipulation (Lenidou and Lenidou, 2009; Yang, 2016). Our topic analysis uses cluster mapping with two orthogonal Cartesian axes in Figure 4, giving a graphical setting, where the horizontal defines a cluster mostly centered on individual wellness or, in contrast, defining an organizational setting, while the vertical is more oriented to a negative consequence/state or a positive way.

In a synthetic description, the position of every record under the same cluster could be in a different graphical area. For example, burnout is a keyword under cluster 1. Many authors define burnout as a syndrome characterized by individual psycho-physic suffering, which can also regard some causes and consequences related to the entire organization of a worker, defining this construct and its cluster negatively, but connected at both an individual and organizational level (Schulz et al., 1995; Yip and Rowlinson, 2009; Brown and Quick, 2013; JonesSchenk, 2019). It emerges as a balanced result, whereby cluster 1 , with the highest number of co-occurrence, is related to psychopathological problems, but the other clusters are positively related to socio-emotional values, where there is a positive influence that improves protective aspects in organizations. The emotional intelligence or other aspects bring potential improvement to organizational performance in terms of a more efficient organization and communication (clusters 3 and 4), personal skills, and inner positive characteristics for better interpersonal competence (clusters 2 and 5) or considering the psychological needs of users and patients to improve their wellness (cluster 6).

Our three hypotheses have been verified by this review.

1. If we consider the last 20 years of research, we notice an incrementation in records considering both emotions and organizational keywords, following a general incrementation trend, whereby emotions are not neglected considering their influence among organizations. There were mild decreases during times of economic recession, for example, during the economic crises of 2008 and 2020, with the beginning of the economic recession caused by movement limitations due to COVID-19, following a new increase.

2. Our cluster analysis revealed prevalence and where emotions are considered negatively, with discussions of stress, burnout, depression, and clinical manifestations due to emotional dysfunction, but we underline that it is just a cluster, whereas the others talk about leadership, gender issues, and organizational performance due to an ethical approach, which also considers emotions as "humanizing" to an organization.

3. Emotions also relate to organizational management, whereby emotions cannot be considered only in an individual way, as single human characteristics, but are also related to organization and people groupings.

For this research, we found many records, even considering only English-language articles and reviews and only using the
SCOPUS database to focus on the research topic. This must be underlined as a limitation, as we excluded other databases.

\section{CONCLUSION}

People working within an organization and the same management rules are strongly moved by a purely rational mechanism, and problems that organizations treat cannot be solved following only rational logic. Kahneman and Tversky (1981), Kahneman (2003), and Thaler and Sunstein (2008), demonstrate that emotions strongly determine important human decisions, even significant financial investments. Recalling the beginning of this study, the theory of separation brings an organizational attitude that spoils the organization from their social function, creating an extremist world consideration, in which an organization cannot consider the possibility of earning money by considering the common good, neglecting environmental sensitivity, labor and political rights, urban sustainable development, and creating wars and exploitation. Trying to overwhelm an ideological approach, the integration of profit and social function must involve socio-emotional elements among organizations introducing social accountability (Hadden, 2012; Tang and Luo, 2016; Bhatia et al., 2020; Dimitropoulos, 2020), which aims to obtain a balanced0 vision between these two dimensions. Emotions are fundamental to moving managers to a major social sensitivity and an ethical approach to business management (Rok, 2009; Fairchild, 2010; Capell and Gabell-Shemueli, 2013; Caldwell and Hayes, 2016; Asgary and Lawrence, 2020), better communication (Dibben, 2004; Swift and Hwang, 2013; Lim et al., 2018), and improved organizational performance (Gabel-Shemueli and Dolan, 2011; Wei and Li, 2011; Bettis-Outland and Guillory, 2018), preventing conflict (Flanagan and Henry, 1994; Leggat and Balding, 2013; Gokturk et al., 2017; Herkes et al., 2019) and suffering (Micael et al., 2008; Richardsson et al., 2008; Skaalvik and Skaalvik, 2011; Martinèz et al., 2013; Rooney and Grant, 2013; Shongwe and Cilliers, 2020). There has been an important incrementation rate during the last 20 years on this topic probably due to the generalized growth of the research. The economic crisis of 20082009 reopened discussion of the importance of social function among entrepreneurial organizations, where the exaggerated free economic speculation of single businessmen damaged Western economies; it was the failure of a liberal system that equaled the fall of the Berlin Wall almost 20 years before, where, on the contrary, there was a socialistic failure with an overcentralized economy, which limited entrepreneurial freedom, creating a closed and not competitive market. The COVID-19 pandemic revealed significant neglect of the socio-emotional influence of human behaviors.

Many countries around the world have delayed a tempestive and preventive intervention and have underestimated the pandemic problem in favor of a short-term economic decision strategy, which does not consider long-term effects and consequences (Zang et al., 2020). Different enterprises, such as fashion firms (Zara, Armani, Zegna, H\&M, Gucci, etc.), have reconverted some of their factories for the production 
of medical instruments. Surely, the smart working, already existing, will receive a better diffusion and application, and any service or selling activities are improving in the educational, medical, or selling sectors (Soled et al., 2020; Spurlock, 2020). An important intervention in many countries is the educational system, changing the teaching style, no longer being based on face-to-face relations (Choe and Choi, 2020). There is now a confrontation between economic superpowers, and Europe has to participate as a single country formed by different nations. There is some financial European aid, which is implementing different economic aid programs for each individual European nation. Moreover, there arebeyond the usual European projects that the EU promotes annually-different specific European projects, such as Pan European Hackaton \#EUvsVirus, which regroups different people from every European country, with different preparations who create different projects to fight the emergency using different focus areas.

This strategy is predominantly insufficient and prioritized economic and sanitarian aspects, where the latter mostly considered just medical aspects without considering a biopsycho-social model (Engel, 1977), which could properly set a better preventive intervention strategy, avoiding a delay of contention strategy against the virus and with chaotic management of the health emergency, where a late intervention by health workers only partially coped with the biological risk, but almost totally neglected the psycho-social negative consequences of the pandemic, creating important discomfort among the population (Griffith, 2020; Banerjee et al., 2021; Jokic-Begic et al., 2021; Szmulewitz et al., 2021; Taylor et al., 2021). COVID-19 is not only a pandemic, which has caused the death of millions of people, but it has also seriously damaged world economies, creating a psycho-social impairment among the population and acting negatively toward organizational vulnerabilities among work and health organizational systems, considering, in this case, only the economic priority, with biological risk as a secondary consideration. However, even in this case, only the medical aspect of this drama was considered, neglecting plenty of effective prevention (better than a cure!) being realized by considering psychological intervention (Hanna-Attisha and Olson, 2021;

\section{REFERENCES}

Adams, I. T., and Mastracci, S. H. (2020). Contrasting emotional labor and burnout in civilian and sworn law enforcement personnel. Policy 43, 314-329. doi: 10.1108/PIJPSM-06-2019-0094

Akerjordet, K., and Severinsson, E. (2007). Emotional intelligence: a review of the literature with specific focus on empirical and epistemological perspectives. J. Clin. Nurs. 16, 1405-1416. doi: 10.1111/j.1365-2702.2006.01749.x

Alzola, M. (2011). The reconciliation project: separation and integration in business ethics projects. J. Bus. Ethics 99, 19-36. doi: 10.1007/s10551-0110746-8

Ameli, S., Eisenberger, R., Fasolo, P., and Linch, P. (1998). Perceived organizational support and police performance: the moderating influence of socioemotional needs. J. Appl. Psychol. 81, 288-297. doi: 10.1037/0021-9010.83. 2.288

Antinyan, A., Bassetti, T., Corazzini, L., and Pavesi, F. (2021). Trust in the health system and COVID-19 treatment. Front. Psychol. 12:643758. doi: 10.3389/fpsyg. 2021.643758
Mimiaga et al., 2021; Zhang et al., 2021). It is difficult to maintain critical thinking in this case, and often people fail in this task because it is easier to follow emotional thinking (Wynes, 2021; Yu et al., 2021), which has often negatively influenced socio-political decisions, for example, creating and maintaining populist movements, which are stronger in uncertain times (Bone, 2021). Stakeholder accountability moves its actions through a complex situation, especially during an actual socio-economic crisis, where there is a significant impairment in terms of social cohesion and trust between people and institutions (Antinyan et al., 2021; Fikukova et al., 2021; Surina et al., 2021; Ye et al., 2021). The accountability of stakeholders means that a single person or a group of people operate for an individual initiative, without an institutional setting, following their own principles, intrinsic rules, and ethics (Salsbury et al., 2018). There are some easy ways to lead in this situation, in which, people must cope with another great challenge: to cooperate with the institution and other people within the same organization or become an autocratic leader, taking every decision alone, deciding easier and faster, but forgetting a democratic approach and risking important mistakes (Zarinah et al., 2017; Hentschel et al., 2018; Levene and Higgs, 2018). History has many examples of "gifted" people in moral and leadership terms who take charge, with all the decision-making power in their hands and guide the destiny of entire countries.

\section{DATA AVAILABILITY STATEMENT}

The original contributions presented in the study are included in the article/supplementary material, further inquiries can be directed to the corresponding author/s.

\section{AUTHOR CONTRIBUTIONS}

TP and GC stated keywords and build the cluster analysis. TP contributed to write and sampling statistics. BH-S and GC contributed to discussion. All authors contributed to the article and approved the submitted version.

Applebaun, S. H., Wenger, S., Pachon-Butriago, C., and Kaur, R. (2016c). The effects of old-age stereotypes on organizational productivity (part one). Ind. Commer. Train. 48, 181-188. doi: 10.1108/ICT-02-2015-0015

Applebaun, S. H., Degbe, M. C., MacDonald, O., and Nguyen-Qang, T. S. (2016a). Organizational outcomes of leadership style and resistance to change (Part one). Ind. Commer. Train. 47, 73-80. doi: 10.1108/ICT-07-2013-0044

Applebaun, S. H., Degbe, M. C., MacDonald, O., and Nguyen-Qang, T. S. (2016b). Organizational outcomes of leadership style and resistance to change (Part two). Ind. Commer. Train. 47, 135-144. doi: 10.1108/ICT-07-2013-0045

Applebaun, S. H., Wenger, S., Pachon-Butriago, C., and Kaur, R. (2016d). The effects of old-age stereotypes on organizational productivity (part two). Ind. Commer. Train. 48, 241-248. doi: 10.1108/ICT-02-2015-0014

Armeli, S., Eisenberger, R., Fasolo, P., and Lynch, P. (1998). Perceived organizational support and police performance: the moderating influence of socioemotional needs. J. Appl. Psychol. 83, 288-297.

Arnold, M. B. (1984). Memory and the Brain. Hillsdale, NJ: Erlbaum.

Asgary, R., and Lawrence, K. (2020). Evaluating underpinning, complexity and implications of ethical situations in humanitarian operations: qualitative study 
through the lens of career humanitarian workers. BMJ Open 10:e039463. doi: 10.1136/bmjopen-2020-039463

Babic, A., Gillis, N., and Hansez, I. (2020). Work-to-family interface and wellbeing: the role of workload, emotional load, support and recognition from supervisors. SA J. Ind. Psychol. 46:a1628. doi: 10.4102/sajip.v46i0.1628

Bakst, S., Romano-Zelekha, O., Ostrovsky, J., and Shohat, T. (2019). Determinants associated with making prenatal screening decisions in a national study. J. Ostet. Ginecol. 39, 41-48. doi: 10.1080/01443615.2018.1463977

Banerjee, D., Kosagisharaaf, J. R., and Sathyanarayana Rao, T. S. (2021). 'The dual pandemic' of suicide and COVID-19: a biopsychosocial narrative of risks and prevention. Psychiatry Res. 275:113577. doi: 10.1016/j.psychres.2020.11 3577

Bao, Y., Vedina, R., Moddie, S., and Dolan, S. (2013). The relationship between value incongruence and individual and organizational well-being outcomes: an exploratory study among Catalan nurses. J. Adv. Nurs. 69, 631-641. doi: $10.1111 / \mathrm{j} .1365-2648.2012 .06045 . \mathrm{x}$

Barbaro, F. (2008). Social structures and social functions: the emancipation of structural analysis in sociology. An Interdiscip. J. Philos. 40-84. doi: 10.1080/ 00201746808601520

Barrena Martinez, J., Lopèz Fernandez, M., and Romero Fernandez, P. M. (2016). Corporate social responsibility: evolution through institutional and stakeholder perspectives. Eur. J. Manag. Bus. Econ. 25, 8-14. doi: 10.1016/j.redee.2015.11. 002

Beck, A. T. (1967). The Diagnosis and Management of Depression. Philadelphia, PA: University of Pennsylvania Press.

Berman, A. T., Rosenthal, S. A., Moghanaki, D., Woodhouse, K. D., Movsas, B., and Vapiwala, N. (2016). Focusing on the "person" in personalized medicine: the future of patient-centered care in radiation oncology. J. Am. Coll. Radiol. 13, 1571-1578. doi: 10.1016/j.jacr.2016. 09.012

Bettis-Outland, H., and Guillory, M. D. (2018). Emotional intelligence and organizational learning at trade shows. J. Bus. Ind. Mark. 33, 126-133. doi: 10.1108/JBIM-03-2017-0066

Bhatia, S., Gupta, G., and Tripathy, A. (2020). The strategic corporate social responsibility (CSR) quandary: an instructional case. Emerald Emerg. Mark. Case Stud. 10, 1-30. doi: 10.1108/EEMCS-12-2019-0344

Blanco, I. (2019). The Unconscious as Infinite Sets: An Essay in Bi-logic. London: Routledge.

Blau, G., Bentley, M. A., and Eggerichs-Purcell, J. (2012). Testing the impact of emotional labor on work exhaustion for three distinct emergency medical service (EMS) samples. Career Dev. Int. 17, 626-645. doi: 10.1108/ 13620431211283788

Bone, J. (2021). Neoliberal precarity and primalization: a biosocial perspective on the age of insecurity, injustice, and unreason. Br. J. Sociol. 72, 1030-1045. doi: $10.1111 / 1468-4446.12884$

Booth, K., and Faulkner, A. (1986). Problems encountered in setting up support groups in nursing. Nurse Educ. Today 6, 244-251. doi: 10.1016/0260-6917(86) 90039-0

Boyatzis, R. E. (2009). Competencies as a behavioral approach to emotional intelligence. J. Manag. Dev. 28, 749-770. doi: 10.1108/02621710910987647

Boyatzis, R. E., and Ratti, F. (2009). Emotional, social and cognitive intelligence competencies distinguishing effective Italian managers and leaders in a private company and cooperatives. J. Manag. Dev. 28, 821-838. doi: 10.1108/ 02621710910987674

Brown, F. W., Bryant, S. E., and Reilly, M. D. (2006). Does emotional intelligence - as measured by the EQI - influence transformational leadership and/or desirable outcomes? Leadersh. Organ. Dev. 25, 330-351. doi: 10.1108/ 01437730610677954

Brown, L. W., and Quick, J. C. (2013). Environmental influences on individual burnout and a preventive approach for organizations. J. Appl. Biobehav. Res. 18, 104-121. doi: $10.1111 /$ jabr.12002

Brunton, M. (2005). Emotion in health care: the cost of caring. J. Health Organ. Manag. 19, 340-354. doi: 10.1108/14777260510615387

Burger-Helmchen, T. (2013). "Entrepreneurial organizations," in Encyclopedia of Creativity, Invention, Innovation and Entrepreneurship, ed. E. G. Carayannis (New York, NY: Springer), doi: 10.1007/978-1-4614-3858-8_208

Burton, R. V. (1963). Generality of honesty reconsidered. Psychol. Rev. 70, 481-499. doi: $10.1037 / \mathrm{h} 0047594$
Caldwell, C., and Hayes, L. A. (2016). Self-efficacy and self-awareness: moral insights to increased leader effectiveness. J. Manag. Dev. 35, 1163-1173. doi: 10.1108/JMD-01-2016-0011

Campbell, A., and Yeung, S. (1991). Creating a sense of mission. Long Range Plan. 24, 10-20. doi: 10.1016/0024-6301(91)90002-6

Cangemi, J. P., Burga, B., Lazarus, H., Miller, R. L., and Fitzgerald, J. (2008). The real work of the leader: a focus on the human side of the equation. J. Manag. Dev. 27, 1026-1036. doi: 10.1108/0262171081091 6286

Capell, B., and Gabell-Shemueli, R. (2013). Public sector values: between the real and the ideal. Cross Cult. Manag. 20, 586-606. doi: 10.1108/CCM-10-20120101

Caprara, G. V., Tisak, M. S., Alessandri, G., Fontaine, R. G., Fida, R., and Paciello, M. (2014). The contribution of moral disengagement in mediating individual tendencies toward aggression and violence. Dev. Psychol. 50, 71-85. doi: 10. 1037/a0034488

Carter, S. (2005). Rational, intelligent organisation: neuroscience and the benefits of feelings. Int. J. Work Organ. Emot. 1, 126-136. doi: 10.1504/IJWOE.2005. 008817

Chen, A. S. Y., Hou, Y. H., and Wu, H. I (2016). Handling conflict at work - the impact of active and agreeable conflict styles. Int. J. Conflict Manag. 27, 50-61. doi: 10.1108/IJCMA-10-2014-0076

Chen, H. X., Xu, X., and Philips, P. (2019). Emotional intelligence and conflict management styles. Int. J. Organ. Anal. 27, 458-470. doi: 10.1108/IJOA-112017-1272

Chiva, R., and Alegre, J. (2008). Emotional intelligence and job satisfaction: the role of organizational learning capability. Pers. Rev. 37, 280-301. doi: 10.1108/ 00483480810906900

Choe, Y. J., and Choi, E. H. (2020). Are we ready for Coronavirus Disease 2019 arriving at schools? J. Korean Med. Sci. 35:e127.

Chrusciel, D. (2006). Considerations of emotional intelligence (EI) in dealing with change decision management. Manag. Decis. 44, 644-657. doi: 10.1108/ 00251740610668897

Cierna, H., and Sujova, E. (2020). Integrating principles of excellence and of socially responsible entrepreneurship. Manag. Syst. Prod. Eng. 28, 23-28. doi: 10.2478/ mspe-2020-0004

Clark, J. M., and Polesello, D. (2017). Emotional and cultural intelligence in diverse workplaces: getting out of the box. Ind. Commer. Train. 49, 337-349. doi: 10.1108/ICT-06-2017-0040

Correa, C., and Larringa, C. (2015). Engagement research in social and environmental accounting. Sustain. Account. Manag. Policy J. 6, 5-28. doi: 10.1108/SAMPJ-09-2014-0058

Coskun, O., Ulutas, I., Budakaglu, I. I., Ugurlu, M., and Utsy, Y. (2018). Emotional intelligence and leadership traits among family physicians. Postgrad. Med. 130, 644-649. doi: 10.1080/00325481.2018.1515563

Crusheil, D. (2006). Considerations of emotional intelligence (EI) in dealing with change decision management. Manag. Decis. 44, 644-657.

Dalrup, V., Krahl, O., and Burger, R. (2020). "Is crowdfunding suitable for financing german public research organization (PRO) projects?” in Contemporary Developments In Entrepreneurial Finance: An Academic And Policy Lens On The Status-Quo, Challenges And Trends, eds A. Moritz, J. H. Block, S. Golla, and A. Werner (Cham: Springer), 309-333. doi: 10.1007/978-3030-17612-9_12

Daniels, C. B. (2009). Improving leadership in a technical environment: a case example of the conits leadership institute. Eng. Manag. J. 21, 47-52. doi: 10. 1080/10429247.2009.11431798

Davies, S., Jenkins, E., and Mabbett, G. (2010). Emotional intelligence: district nurses' lived experiences. Br. J. Commun. Nurs. 15, 141-146. doi: 10.12968/bjcn. 2010.15.3.46903

Deckard, G. J., and Present, R. M. (1989). Impact on role stress on physical therapists' emotional and physical well-being. Phys. Ther. 29, 713-718. doi: $10.1093 / \mathrm{ptj} / 69.9 .713$

Der Foo, M., Elfenbein, H. A., Tan, H. H., and Aik, V. C. (2004). Emotional intelligence and negotiation: the tension between creating and claiming value. Int. J. Conflict Manag. 15, 411-429. doi: 10.1108/eb022920

Dhliwayo, P., and Coetze, M. (2020). Cognitive intelligence, emotional intelligence and personality types as predictors of job performance: exploring a model for 
personnel selection. SA J. Hum. Resour. Manag. 18:a1348. doi: 10.4102/sajhrm. v18i0.1348

Dibben, M. N. (2004). Exploring the processual nature of trust and cooperation in organisations: a whiteheadian analysis. Phylosophy Manag. 4, 25-39. doi: 10.5840/pom 20044112

Dijkstra, M. T. M., Van Dierendock, D., Evers, A., and De Preu, C. K. W. (2005). Conflict and well-being at work: the moderating role of personality. J. Manag. Psychol. 20, 87-104. doi: 10.1108/02683940510579740

Dimitropoulos, P. E. (2020). Corporate social responsibility and earnings management in the EU: a panel data analysis approach (article in press). Soc. Responsib. J. 1-17. doi: 10.1108/SRJ-04-2020-0156

Donnay, F., Bregentzer, A., Leemans, P., Verougstraete, A., and Vekemans, M. (1993). Safe abortions in an illegal context: perceptions from service providers in Belgium. Stud. Fam. Plan. 24, 150-162. doi: 10.2307/2939230

Driller, E., Ommen, O., Kowalski, C., Ersnstman, N., and Pfaff, H. (2011). The relationship between social capital in hospitals and emotional exhaustion in clinicians: a study in four German hospitals. Int. J. Soc. Psychiatry 57, 604-609. doi: $10.1177 / 0020764010376609$

Dubler, N. N. (1995). The doctor-proxy relationship: the neglected connection. Kennedy Inst. Ethic J. 5, 289-306. doi: 10.1353/ken.0.0127

Duncan, B. A., and Siegal, A. P. (1998). Early diagnosis and management of Alzheimer's disease. J. Clin. Psychiatry 59, 15-21.

Elizandro, D., Volpe, A. A., and Huddlestone, D. H. (2018). "A system approach to stakeholder engagement in accountability of regional universities," in Proceedings of the Annual Conference Exposition, Conference Proceedings. 125th ASEE Annual Conference Exposition, Salt Lake City, UT.

Engel, G. L. (1977). The need for a new medical model: a challenge for biomedicine. Science 196, 129-136. doi: 10.1126/science. 847460

Erim, Y., Kahraman, Y., Vitinius, F., Beckman, M., Kronke, S., and Winkman, O. (2015). Resilience and quality of life in 161 living kidney donors before nephrectomy and in the aftermath of donation: a naturalistic single center study. BMC Nephrol. 16:164. doi: 10.1186/s12882-015-0160-z

Escamilla-Fajardo, P., Nunez-Pomar, J. M., and Gomeza-Tafaja, A. M. (2020). Exploring environmental and entrepreneurial antecedents of social performance in Spanish sports clubs: a symmetric and asymmetric approach. Sustainability 12:4234. doi: 10.3390/su12104234

Evans, M. E. (2006). Integrating nursing care into systems of care for children with emotional and behavioral disorders. J. Adolesc. Psychiatr. Nurs. 19, 62-68. doi: $10.1111 / j .1744-6171.2006 .00053 . x$

Fairchild, R. M. (2010). Practical ethical theory for nurses responding to complexity in care. Nurs. Ethics 17, 353-362. doi: 10.1177/0969733010361442

Figueroa-Armijos, M., and Berns, J. P. (2021). Vulnerable populations and individual social responsibility in Prosocial Crowdfunding: does the framing matter for female and rural entrepreneurs? J. Bus. Ethics 1-16. doi: 10.1007/ s10551-020-04712-0

Fikukova, P., Ayton, P., Rand, K., and Langguth, J. (2021). What should I trust? Individual differences in attitudes to conflicting information and misinformation on COVID-19. Front. Psychol. 12:588478. doi: 10.3389/fpsyg. 2021.588478

Flanagan, H. D., and Henry, P. (1994). Healthy working and performance management. A discussion of the approach and a report on a survey of NHS organizations. Health Manpower Manag. 20, 22-32. doi: 10.1108/ 09552069410060067

Fowlie, J., and Wood, M. (2009). The emotional impact of leaders' behaviours. J. Eur. Ind. Train. 33, 559-572. doi: 10.1108/03090590910974428

Freeman, D. G. M., and Carson, M. (2006). Developing workplace resilience: the role of the peer referral agent diffuser. J. Workplace Behav. Health 22, 113-121. doi: 10.1300/J490v22n01_08

Freeman, R. E. (2000). Business ethics at the Millenium. Glob. Ethics Bus. 10, 169-180.

Freeman, R. E., Wicks, A. C., and Parmar, B. (2004). Stakeholder theory and "the corporate objective revisited”. Organ. Sci. 15, 364-369. doi: 10.1287/orsc.1040. 0066

Freud, S. (1911). Formulations on the Two Principles of Mental Functioning. The Standard Edition of the Complete Psychological Works of Sigmund Freud. London: Routledge.

Friedman, M. (1962). Capitalism and Freedom. Chicago, IL: University of Chicago Press, doi: 10.1086/447510
Gabel-Shemueli, R., and Dolan, S. (2011). Do emotions matter? The role of emotional intelligence competences in cross-cultural adjustment for international assignment. Manag. Res. 9, 207-229. doi: 10.1108/1536541111181912

Galtseva, T., Switch, S., Kutsy, A., Savchenko, V., and Strukova, S. (2020). Education for sustainable development in the value system of teachers. Eur. J. Sustain. Dev. 9, 147-160. doi: 10.14207/ejsd.2020.v9n4p147

Galvin, M. R., Fletcher, J., and Stilwell, B. M. (2006). Assessing the meaning of suicidal risk behavior in adolescents: three exercises for clinicians. J. Am. Acad. Child Adolesc. Psychiatry 45, 745-748. doi: 10.1097/01.chi.0000215346.86278. 61

Gellatelly, R., and Kiernan, B. (2003). “The study of mass murder and genocide," in The Specter of Genocide: Mass Murder in Historical Perspective, eds R. Gellately and B. Kiernan (Cambridge: Cambridge University Press), 3-26. doi: 10.1017/ CBO9780511819674.001

Gil-Rivas, V., Handrup, C. T., Tanner, E., and Walker, D. K. (2019). Global mental health: a call to action. Am. J. Ortopsychiatry 89, 420-425. doi: 10.1037/ ort0000373

Glaser, W., and Hect, T. D. (2013). Work-family conflicts, threat-appraisal, selfefficacy and emotional exhaustion. J. Manag. Psychol. 28, 164-182. doi: 10.1108/ 02683941311300685

Goetz, T., Frenzel, A. C., Pekrun, R., and Hall, N. C. (2006). The domain specificity of academic emotional experiences. J. Exp. Educ. 75, 5-29. doi: 10.3200/JEXE. 75.1.5-29

Gokturk, S., Bozoglu, O., and Guncavdi, G. (2017). Error management practices interacting with national and organizational culture: the case of two state university departments in Turkey. Learn. Organ. 24, 245-256. doi: 10.1108/ TLO-07-2016-0041

Goleman, D. (1996). Emotional Intelligence: Why it Can be More Than IQ. New York, NY: Bantam books.

Goodnow, J. J. (1990). Using sociology to extend psychological accounts of cognitive development. Hum. Dev. 33, 81-107. doi: 10.1159/00027 6505

Gordon, N. S., and Winpenny, P. (1996). A critical reflection on the personal impact of managerial hegemony within nurse education. J. Adv. Nurs. 23, 479-486. doi: 10.1111/j.1365-2648.1996.tb00009.x

Graca, M. M. (2017). Shumpeter and the meanings of rationality. J. Evol. Econ. 27, 115-138. doi: 10.1007/s00191-015-0429-1

Gray, B. (2009). The emotional labour of nursing - Defining and managing emotions in nursing work. Nurse Educ. 29, 168-175. doi: 10.1016/j.nedt.2008. 08.003

Gray, B. (2010). Emotional labour, gender and professional stereotypes of emotional and physical contact, and personal perspectives on the emotional labour of nursing. J. Gender Stud. 19, 349-360. doi: 10.1080/09589236.2010. 514207

Griffith, A. K. (2020). Parental burnout and child maltreatment during the COVID19 pandemic. J. Fam. Violence 1-5. doi: 10.1007/s10896-020-00172-2

Gronstad, A. S. (2017). Exploring work-related attributions of sickness absence during organizational change: a scoping review. Int. J. Workplace Health Manag. 10, 192-212. doi: 10.1108/IJWHM-03-20160012

Gupchup, G. V., Lively, B. T., Holiday-Goodman, M., Siganga, W. W., and Black, C. D. (1994). Maslach Burnout Inventory: factor structures for pharmacists in health maintenance organizations and comparison with normative data for USA pharmacists. Psychol. Rep. 74, 891-895. doi: 10.2466/pr0.1994.74. 3.891

Hadden, T. (2012). Accountable governance in corporate groups: the interrelationship of law and accounting. Aust. Account. Rev. 22, 117-128. doi: 10.1111/j.1835-2561.2012.00167.x

Hanna-Attisha, M., and Olson, E. D. (2021). Preexisting conditions that kill us. Fam. Commun. Health 44, 76-77. doi: 10.1097/FCH.0000000000000288

Hartman, E. M. (2011). "Freeman: win-win and the common good (book chapter)," in Stakeholder Theory: Impact and Prospects, ed. R. A. Phillips (Cheltenham: Elgar), 76-98.

Hentschel, T., Braun, S., Peus, C., and Frey, D. (2018). The communalitybonus effect for male transformational leaders - leadership style, gender, and promotability. Eur. J. Work Organ. Psychol. 27, 112-125. doi: 10.1080/ 1359432X.2017.1402759 
Herkes, J., Ellis, L. A., Churruca, K., and Braithwaite, J. (2019). A cross-sectional study investigating the associations of person-organisation and person-group fit with staff outcomes in mental healthcare. BMJ Open 9, e030669. doi: 10.1136/ bmjopen-2019-030669

Hess, J. D., and Bacigalupo, A. C. (2010). The emotionally intelligent leader, the dynamics of knowledge-based organizations and the role of emotional intelligence in organizational development. Horizon 18, 222-229. doi: 10.1108/ 10748121011072672

Ho, D. (2007). Work discussion groups in clinical supervision in mental health nursing. Br. J. Nurses (Mark Allen Publishing) 16, 39-42, 44-46. doi: 10.12968/ bjon.2007.16.1.22714

Hopkins, M. M. O., Neil, D. A., and Williams, H. W. (2007). Emotional intelligence and board governance: leadership lessons from the public sector. J. Manag. Psychol. 22, 683-700. doi: 10.1108/02683940710820109

Hoppe, R. B. (1983). Decision theory and health resource allocations. Theor. Med. 4, 193-205. doi: 10.1007/BF00562892

Hujala, A., and Rissanen, S. (2011). Organization aesthetics in nursing homes. J. Nurs. Manag. 19, 439-448. doi: 10.1111/j.1365-2834.2011.01193.x

Humphreys, J., Brunsen, B., and Davis, D. (2005). Emotional structure and commitment: implications for health care management. J. Health Organ. Manag. 1, 120-129. doi: 10.1108/14777260510600040

Hur, W. M., Han, S. J., Yoo, J. J., and Moon, T. W. (2015). The moderating role of perceived organizational support on the relationship between emotional labor and job-related outcomes. Manag. Decis. 53, 605-614. doi: 10.1108/MD-072013-0379

Huynh, J. Y., Xantopulou, D., and Winefield, A. H. (2014). The Job DemandsResources Model in emergency service volunteers: examining the mediating roles of exhaustion, work engagement and organizational connectedness. Work Stress 28, 305-322. doi: 10.1080/02678373.2014.936922

Igarashi, H., Kibuchi, H., Kano, R., Mitoma, H., Shono, M., Hasui, C., et al. (2009). The inventory of personality organisation: its psychometric properties among student and clinical populations in Japan. Ann. Gen. Psychiatry 8:9. doi: 10.1186/1744-859X-8-9

Inal, V., Kitapscioglu, G., Karabulut, G., and Kabasakal, Y. (2010). Evaluation of quality of life in relation to anxiety and depression in primary Sjögren's syndrome. Modern Reumathol. 20, 588-597. doi: 10.1007/s10165-0100329-z

Jafri, M. A., Minhas, F. A., Tamiz-Ud-Din, A., Slatch, M. A., and Mujeeb, F. (2011). Knowledge of depression among community members and health care providers in two selected areas of district Rawalpindi. J. Coll. Phys. Surg. Pak. 21, 757-759.

Johnson, H., Worthington, R., Gredecki, N., and Wilks-Riley, F. R. (2016). The impact of forensic work on home life: the role of emotional labour, segmentation/integration and social support. J. Forensic Pract. 18, 52-63. doi: 10.1108/JFP-05-2015-0029

Jokic-Begic, N., Korajlija, A. L., and Begic, D. (2021). Mental health of psychiatrists and physicians of other specialties in early covid-19 pandemic: risk and protective factors. Psychiatr. Danubina 32, 536-548. doi: 10.24869/PSYD.2020. 536

Jones-Schenk, J. (2019). Burnout, 3.0. J. Contin. Educ. Nurs. 50, 345-346. doi: 10.3928/00220124-20190717-03

Jorm, C., Jedema, R., Piper, D., Goodwin, N., and Searles, A. (2021). "Slow science” for 21st century healthcare: reinventing health service research that serves fast-paced, high-complexity care organisations. J. Health Organ. Manag. 35, 701-716. doi: 10.1108/JHOM-06-2020-0218

Kahili, A. (2017). Transformational leadership and organizational citizenship behavior: the moderating role of emotional intelligence. Leadersh. Organ. Dev. J. 38, 1004-1015. doi: 10.1108/LODJ-11-2016-0269

Kahneman, D. (2003). Maps of bounded rationality: psychology for behavioral economics. Am. Econ. Rev. 93, 1449-1475. doi: 10.1257/000282803322655392

Kahneman, D., and Tversky, A. (1981). Judgment under uncertainty: heuristics and Biases. Science 185, 1124-1131. doi: 10.1126/science.185.4157.1124

Karatepe, O. M. (2015). Do personal resources mediate the effect of perceived organizational support on emotional exhaustion and job outcomes? Int. J. Contemp. Hosp. Manag. 27, 4-26. doi: 10.1108/IJCHM-09-2013-0417

Karatepe, O. M., and Tekinus, M. (2006). The effects of work-family conflict, emotional exhaustion, and intrinsic motivation on job outcomes of front-line employees. Int. J. Bank Mark. 24, 173-193. doi: 10.1108/02652320610659021
Karatepe, O. M., and Zargar-Tizabi, L. (2011). Work-related depression in the hotel industry: a study in the United Arab Emirates. Int. J. Contemp. Hosp. Manag. 23, 608-623. doi: 10.1108/09596111111143368

Kent, T. W. (2006). Leadership and emotions in health care organizations. J. Health Organ. Manag. 21, 49-66. doi: 10.1108/14777260610656552

Kerr, R., Garvin, J., Heaton, L., and Boyle, E. (2006). Emotional intelligence and leadership effectiveness. Leadersh. Organ. Dev. J. 27, 265-279. doi: 10.1108/ 01437730610666028

Kim, K. Y., Eisenberger, R., and Baik, K. (2016). Perceived organizational support and affective organizational commitment: moderating influence of perceived organizational competence. J. Organ. Behav. 37, 558-583. doi: 10.1002/job.2081

Kirzner, I. M. (2019). The ethics of pure entrepreneurship: an Austrian economics perspective. Rev. Aust. Econ. 32, 89-99. doi: 10.1007/s11138-0170412-1

Knight, J. K., Chmiel, J. S., Sharp, L. K., Kuzel, T., Nadler, R. B., Fine, R., et al. (2001). Spouse ratings of quality of life in patients with metastatic prostate cancer of lower socioeconomic status: an assessment of feasibility, reliability, and validity. Urology 57, 275-280. doi: 10.1016/S0090-4295(00)00934- 1

Koman, E. S., and Wolff, E. B. (2008). Emotional intelligence competencies in the team and team leader: a multi-level examination of the impact of emotional intelligence on team performance. J. Manag. Dev. 27, 55-75. doi: 10.1108/ 02621710810840767

Krajcsàk, Z. (2018). Making high committed workplaces by strong organizational values. J. Hum. Values 24, 127-137. doi: 10.1177/0971685818764064

Krebs, D. (1975). Empathy and altruism. J. Pers. Soc. Psychol. 32, 1134-1143. doi: 10.1037/0022-3514.32.6.1134

Kurtessis, J. N., Eisenberger, R., Ford, M. T., FUffardi, M. C., Stewart, K. A., and Adis, C. S. (2017). Perceived organizational support: a meta-analytic evaluation of organizational support theory. J. Manag. 44, 1854-1884. doi: $10.1177 / 0149206315575554$

Lawrence, A., Wong, J. L. G., and Molteno, S. (2020). Fostering social enterprise in woodlands: challenges for partnerships supporting social innovation. Forest Policy Econ. 118:102221. doi: 10.1016/j.forpol.2020.102221

LeDoux, J., Meyer, W. J. III, Blakeney, P. E., and Herndon, P. N. (1998). Relationship between parental emotional states, family environment and the behavioural adjustment of pediatric burn survivors. Burns 24, 425-432. doi: 10.1016/S0305-4179(98)00038-2

Lee, S., and Lehdonvirta, V. (2020). New digital safety net or just more 'friendfunding'? Institutional analysis of medical crowdfunding in the United States [early access]. Inf. Commun. Soc. 1-25. doi: 10.1080/1369118X. 2020.1850838

Leggat, S. G., and Balding, C. (2013). Achieving organisational competence for clinical leadership: the role of high performance work systems. J. Health Organ. Manag. 27, 312-329. doi: 10.1108/JHOM-Jul-2012-0132

Lenidou, L. C., and Lenidou, C. N. (2009). Rational versus emotional appeals in newspaper advertising: copy, art, and layout differences. J. Promot. Manag. 15, 522-546. doi: 10.1080/10496490903281353

Levene, F., and Higgs, M. (2018). Leadership and change implementation in a Russian context. J. Gen. Manag. 44, 5-16. doi: 10.1177/030630701878 0406

Liberati, A., Altman, D. G., Tetzlaff, J., Mulrow, C., Gøtzsche, P. C., Ioannidis, J. P., et al. (2009). The PRISMA statement for reporting systematic reviews and meta-analyses of studies that evaluate healthcare interventions: explanation and elaboration. Ital. J. Public Health 7, 354-391.

Lierville, A. L., Grou, C., and Pelletier, J. F. (2015). Issues, dilemmas and managerial strategies of potential ethical risks associated with the implementation of patient partnership practices in psychiatry: a case study. Sante Ment. Quebec 40, 119-134. doi: 10.7202/1032386ar

Lim, S. H., Han, S. S., and Yoo, Y. S. (2018). Effects of nurses' emotional intelligence on their organizational citizenship behavior, with mediating effects of leader trust and value congruence. Jpn. J. Nurs. Sci. 15, 363-374. doi: 10.1111/jjns. 12206

Lindebaum, D., and Cartwright, S. (2011). Leadership effectiveness: the costs and benefits of being emotionally intelligent. Leadersh. Organ. Dev. J. 32, 281-290. doi: 10.1108/01437731111123924

Linden, M., Salo, I., and Janson, A. (2018). Organizational stressors and burnout in public librarians. J. Librariansh. Inf. Sci. 20, 199-204. doi: 10.1177/ 0961000616666130 
Link, H. C. (1922). Practices and services of the Psychological Service Center. J. Consult. Psychol. 2, 149-154. doi: 10.1037/h0062554

Lomakina, N. F. (2020). Development of entrepreneurship in the field of medical care based on the franchising model. Probl. Sotsialnoi Gig. Zdravookhraneniia Istor. Med. 28, 766-772. doi: 10.32687/0869-866X-2020-28-s1-766-772

Lombard, D. (2021). Person-centred communication in long-term care with older people: a scoping review. J. Integr. Care 29, 306-333. doi: 10.1108/JICA-102020-0070

Loosemore, M. (2010). Using multimedia to effectively engage stakeholders in risk management. Int. J. Manag. Project Bus. 3, 307-327. doi: 10.1108/ 17538371011036608

Lounsbury, J. W., Sundstrom, E. D., Gibson, L. W., Loveland, J. M., and Drost, A. W. (2016). Core personality traits of managers. J. Manag. Psychol. 31, 434-450. doi: 10.1108/JMP-03-2014-0092

MacNeil, B. M., Lopes, V. A., and Minnes, P. M. (2009). Anxiety in children and adolescents with autism spectrum disorders. Res. Autism Specrtum Disord. 3, 1-21. doi: 10.1016/j.rasd.2008.06.001

Magala, S. (2002). Cold war and hot issues: management of responsibilities. Hum. Resour. Dev. Int. 5, 493-505. doi: 10.1080/13678860210166726

Malik, A. A., Bhatti, S., Shafiq, A., Kahn, R. S., Butt, U. I, Bilal, S. M., et al. (2016). Burnout among surgical residents in a lower-middle income country - Are we any different? Ann. Med. Surg. 9, 28-32. doi: 10.1016/j.amsu.2016.05.012

Manzoor, H., Johnson, N. N., and Rashid, M. (2018). Emotions during executive succession in a public board. J. Organ. Change Manag. 3, 766-776. doi: 10.1108/ JOCM-09-2016-0174

Martinèz, P., Galdon, M. J., Andreu, Y., and Ibanez, J. (2013). The Distress Thermometer in Spanish cancer patients: convergent validity and diagnostic accuracy. Support. Care Cancer 21, 3095-3102. doi: 10.1007/s00520-013-18837

McCracken, M. (2005). Towards a typology of managerial barriers to learning. J. Manag. Dev. 24, 559-575. doi: 10.1108/02621710510601008

McVea, J. F., and Freeman, R. E. (2003). A names-faces approach to stakeholder management how focusing on stakeholders as individuals can bring ethics and entrepreneurial strategy together. J. Manag. Inquiry 14, 57-69. doi: 10.1177/ 1056492604270799

Meisler, G. (2014). Exploring emotional intelligence, political skill, and job satisfaction. Employee Relat. 36, 280-293. doi: 10.1108/ER-02-2013-0021

Meisler, G., and Vigoda Gadot, E. (2014). Perceived organizational politics, emotional intelligence and work outcomes: empirical exploration of direct and indirect effects. Pers. Rev. 43, 116-135. doi: 10.1108/PR-02-2012-0040

Mensik, M. (2019). Business and Finance, Spationomy: Spatial Exploration of Economic Data and Methods of Interdisciplinary Analytics. Cham: Springer. doi: 10.1007/978-3-030-26626-4_6

Micael, O., Court, D., and Petal, P. (2008). Job stress and organizational commitment among mentoring coordinators. Int. J. Int. Manag. 23, 266-288. doi: 10.1108/09513540910941766

Micaelson, C. (2021). A normative meaning of meaningful work. J. Bus. Ethics 170, 413-428. doi: 10.1007/s10551-019-04389-0

Miceli, M., and Castelfranchi, C. (2018). Contempt and disgust: the emotions of disrespect. J. Theory Soc. Behav. 48, 205-229. doi: 10.1111/jtsb.12159

Mimiaga, M. J., Hugto, M. J. W., Klasko-Foster, M., Jin, H., Mayer, K. H., Safren, S. A., et al. (2021). Substance use, mental health problems, and physical and sexual violence additively increase HIV risk between male sex workers and their male clients in Northeastern United States. J. Acquir. Immune Defic. Syndr. 86, 305-312.

Molter, N. C. (2003). Creating a healing environment for critical care. Crit. Care Nurs. Clin. North Am. 15, 295-304. doi: 10.1016/S0899-5885(02)00049-7

Moran, R. A. (1976). Social responsibility, entrepreneurship, and goal of firms: an examination of current economic literature. Forum 6, 45-54. doi: 10.1007/ BF02753282

Morehouse, M. M. (2007). An exploration of emotional intelligence across career arenas. Leadersh. Organ. Dev. J. 28, 296-307. doi: 10.1108/01437730710752184

Morell, M. F., Hidalgo, E. S., and Rodriguez, E. (2020). Goteo.org civic crowdfunding and match-funding data connecting sustainable development goals. Sci. Data 7:132. doi: 10.1038/s41597-020-0472-0

Motero, N. L., Gomez, E. H., and Penalver, A. J. B. (2021). Crowdfunding. The alternative to traditional financing of social projects. Revesco Rev. Estud. Cooperativos 136:e71851. doi: 10.5209/REVE.71851
Mularz, L. A., and Johansen, M. L. (2016). An educational program to promote emotional mastery skills in nurse managers. J. Nurses Prof. Dev. 32, E1-E7. doi: $10.1097 /$ NND.0000000000000246

Naslund, H. (2020). Collective deliberations and hearts on fire: experiential knowledge among entrepreneurs and Organisations in the mental health service user movement. Voluntas 1-12. doi: 10.1007/s11266-020-00233-6

Nikodemska-Wolowik, A. M. (2008). "Towards human face of economy - ethical aspects of contemporary business," in Proceedings of the 5th International Scientific Conference Business and Management, eds R. Ginevičius, A. V. Rutkauskas, K. Didenko, T. Polajeva and J. Saee (Vinius: Vilnius Gediminas Technical University, Business Management Faculty).

Oliver, D., and Jacobs, C. D. (2007). Developing guiding principles: an organizational learning perspective. J. Organ. Change Manag. 20, 813-828. doi: 10.1108/09534810710831037

Ostaszkiewicz, J. O., Connel, B., and Dunning, T. (2016). 'We just do the dirty work' dealing with incontinence, courtesy stigma and the low occupational status of carework in long-term aged care facilities. J. Clin. Nurs. 25, 2528-2541. doi: $10.1111 /$ jocn. 13292

Pandley, J. (2018). Managing emotional labor for service employees: an HRMbased approach. Hum. Manag. Resour. Int. Digest 26, 1-4. doi: 10.1108/ HRMID-04-2017-0072

Pavlidou, I., Papagiannidis S., and Tsui, E. (2020). Crowdsourcing: a systematic review of the literature using text mining. Ind. Manag. Data Syst. 120, 2041-2065. doi: 10.1108/IMDS-08-2020-0474

Peng, K. Z., Wong, C. S., and Che, H. S. (2010). The missing link between emotional demands and exhaustion. J. Manag. Psychol. 25, 777-798. doi: 10. $1108 / 02683941011075300$

Penticuff, J. H. (1989). Infant suffering and nurse advocacy in neonatal intensive care. Nurs. Clin. North Am. 24, 987-997.

Perez-Fuentes, M. D. C., Molero-Jurado, M. D. M., Del Pino, R. M., and Gazquez Linares, J. J. (2019). Emotional intelligence, self-efficacy and empathy as predictors of overall self-esteem in nursing by years of experience. Front. Psychol. 10:2035. doi: 10.3389/fpsyg.2019.02035

Powell, T., and Kornfeld, D. S. (1993). Can we measure out a life in coffee spoons? J. Clin. Ethics 110-111. Available online at: https://pubmed-ncbi-nlm-nih-gov. ezproxy.usal.es/11643061/

Prada-Ospina, R. (2019). Social psychological factors and their relation to workrelated stress as generating effect of burnout. Interdisciplinaria 36, 39-53. doi: 10.16888/interd.2019.36.2.3

Predkiewcz, K., and Kalinowska-Beszczynska, O. (2020). Financing eco-projects: analysis of factors influencing the success of crowdfunding campaigns [early access]. Int. J. Entrepreneurial Behav. Res. 27, 547-566. doi: 10.1108/IJEBR-052020-0339

Rahmani, H., Azari, S., Vasokolaee, G. R., Mirghaed, M. T., and Raadabadi, M. (2015). Organizational culture and the organizational commitment; Correlational study in hospital staffs. Asian Soc. Sci. 11, 143-149. doi: 10.5539/ ass.v11n5p143

Rama-Maceiras, P., Parente, S., and Kranke, P. (2012). Job satisfaction, stress and burnout in anaesthesia: relevant topics for anaesthesiologists and healthcare managers? Am. J. Anaesthesiol. 29, 311-319. doi: 10.1097/EJA. 0b013e328352816d

Ramo, L. G., Saris, W. E., and Boyatzis, R. E. (2009). The impact of social and emotional competencies on effectiveness of Spanish executives. J. Manag. Dev. 28, 771-773. doi: 10.1108/02621710910987656

Rayner, E. (1995). Unconscious Logic: An Introduction to Matte Blanco's Bi-logic and its Uses. London: Routledge.

Razzak, M. R., Abu Bakar, R., and Mustamil, N. (2019). Socioemotional wealth and performance in private family firms. J. Entrepreneursh. Emerg. Econ. 11, 392-415. doi: 10.1108/JEEE-07-2018-0074

Reed, F. M., Fitzgerald, L., and Bish, M. R. (2018). A practice model for rural district nursing success in end-of-life advocacy care. Scand. J. Caring Sci. 32, 746-755. doi: $10.1111 / \mathrm{scs} .12505$

Richardsson, H. A., Yang, J., Venderberg, R. J., Dejoy, D. M., and Wilson, M. J. (2008). Perceived organizational support's role in stressor-strain relationships. J. Manag. Psychol. 23, 789-810. doi: 10.1108/02683940810896349

Robinson, J. R., Clements, K., and Land, C. (2003). Workplace stress among psychiatric nurses: prevalence, distribution, correlates, \& predictors. J. Psychosoc. Nurs. Mental Health Serv. 41, 32-41. 
Rok, B. (2009). People and skills ethical context of the participative leadership model: taking people into account. Corp. Gov. 9, 461-472. doi: 10.1108/ 14720700910985007

Rooney, A., and Grant, R. (2013). Pharmacological treatment of depression in patients with a primary brain tumour. Cochr. Database Syst. Rev. 2013:CD006932. doi: 10.1002/14651858.CD006932.pub3

Rustoen, T. (1998). Nursing intervention to increase hope in cancer patients. J. Clin. Nurs. 7, 19-27. doi: 10.1046/j.1365-2702.1998.00126.x

Salami, S. O. (2008). Psychosocial factors as predictors of mentoring among nurses in southwestern Nigeria. J. Workplace Learn. 20, 348-363. doi: 10.1108/ 13665620810882941

Saleh, S. N., Lehman, C. U., and Medford, R. J. (2021). Early crowdfunding response to the COVID-19 pandemic: cross-sectional study. J. Med. Intern. Res. 23:e25429. doi: $10.2196 / 25429$

Salsbury, S. A., Vining, R. D., Gosselin, D., and Goertz, C. M. (2018). Be good, communicate, and collaborate: a qualitative analysis of stakeholder perspectives on adding a chiropractor to the multidisciplinary rehabilitation team. Chiropr. Man. Therap. 26:29. doi: 10.1186/s12998-018-0200-4

Schulz, R., Greenley, J. R., and Brown, R. (1995). Organization, management, and client effects on staff burnout. J. Health Soc. Behav. 36, 333-345. doi: 10.2307/ 2137323

Schwarz, L., Sippel, S., Entwistle, A., Hell, A. K., and Koenig, S. (2016). Biographic characteristics and factors perceived as affecting female and male careers in academic surgery: the tenured gender battle to make it to the top. Eur. Surg. Res. 57, 139-154. doi: 10.1159/000446874

Segalla, S. G. M., Van Eyll, B., Federico, M. H. H., Skare, N. G., Franke, F. A., Perdicaris, M. R., et al. (2008). Evaluation of quality of life in patients with metastatic colorectal cancer treated with capecitabine. Clin. Colectoral Cancer 7, 126-133. doi: 10.3816/CCC.2008.n.017

Sengelov, L., Frolich, S., Kamby, C., Yensen, N. H., and Steven, K. (2000). The functional and psychosocial status of patients with disseminated bladder cancer. Urol. Oncol. 5, 20-24.

Serwint, J. R., and Stewart, M. T. (2019). Cultivating the joy of medicine: a focus on intrinsic factors and the meaning of our work. Curr. Probl. Pediatr. Adolesc. Health Care 49:100665. doi: 10.1016/j.cppeds.2019.100665

Severinsson, E. I., and Hallberg, I. L. (1996). Clinical supervisors' views of their leadership role in the clinical supervision process within nursing care. J. Adv. Nurs. 24, 151-161. doi: 10.1046/j.1365-2648.1996.17321.x

Seyedpour, S. M., Safari, A., and Nasr Isfarani, I. (2020). Formulating an organizational pride model for the National Iranian Oil Company. Cogement Bus. Manag. 7:1794679. doi: 10.1080/23311975.2020.179 4679

Sheldon, L. K., Blonquist, T. M., Hilaire, D. M., Hong, F., and Barry, D. M. (2015). Patient cues and symptoms of psychosocial distress: what predicts assessment and treatment of distress by oncology clinicians? Psycho Oncol. 24, 1020-1027. doi: 10.1002/pon.3689

Shi, J. T., Yang, K. L., Xu, W., and Wang, M. M. (2021). Leveraging deep learning with audio analytics to predict the success of crowdfunding projects. J. Supercomput. 77, 7833-7853. doi: 10.1007/s11227-020-03595-2

Shihi, H. A., and Susanto, E. (2010). Conflict management styles, emotional intelligence, and job performance in public organizations. Int. J. Conflict Manag. 21, 147-168. doi: 10.1108/10444061011037387

Shin, I., Hur, W. M., and Oh, H. (2015). Essential precursors and effects of employee creativity in a service context: emotional labor strategies and official job performance. Career Dev. Int. 20, 733-753. doi: 10.1108/CDI-10-20140137

Shongwe, M., and Cilliers, F. (2020). The systems psychodynamic experiences of professionals appointed in acting capacities. SA J. Ind. Psychol. 46:a1785. doi: $10.4102 /$ sajip.v46i0.1785

Skaalvik, E. M., and Skaalvik, S. (2011). Teachers' feeling of belonging, exhaustion, and job satisfaction: the role of school goal structure and value consonance. Anxiety Stress Coping 24, 369-385. doi: 10.1080/10615806.2010.544300

Soled, D., Goel, S., Barry, D., Erfani, P., Joseph, N., Kochis, M., et al. (2020). Medical student mobilization during a crisis: lessons from a COVID-19 medical student response team. Acad. Med. 95, 1384-1387. doi: 10.1097/ACM. 0000000000003401

Solloway, M., LaFrance, S., Bakitas, M., and Gerken, M. (2005). A chart review of seven hundred eighty-two deaths in hospitals, nursing homes, and hospice/home care. J. Palliative Medicine 8, 789-796. doi: 10.1089/jpm.2005.8. 789

Spurlock, D. Jr. (2020). Scholarship during the pandemic: secondary data analisys. J. Nurs. Education 59, 245-247.

Srivastava, S., and Argawal, S. (2020). Workplace bullying and intention to leave: a moderated mediation model of emotional exhaustion and supervisory support. Employee Relat. 42, 1547-1563. doi: 10.1108/ER-07-2019-0293

Srivastava, S., and Dey, B. (2020). Workplace bullying and job burnout: a moderated mediation model of emotional intelligence and hardiness. Int. J. Organ. Anal. 28, 183-204. doi: 10.1108/IJOA-02-2019-1664

Srivastava, S., Jain, A. K., and Sullivan, S. (2019). Employee silence and burnout in India: the mediating role of emotional intelligence. Pers. Rev. 4, 1045-1060. doi: 10.1108/PR-03-2018-0104

Starbuck, W. H. (2017). Organizational learning and unlearning. Learn. Organ. 24 , 30-38. doi: 10.1108/TLO-11-2016-0073

Stawicki, S. P. A., and Firstenberg, M. S. (2018). Fundamentals of Leadership for Healthcare Professionals. Hauppauge, NY: Nova Science Publishers, Inc.

Stone, P. W., Du, Y., Cowell, R., Amserdam, N., Helfrich, T. A., Linn, R. W. et al. (2006). Comparison of nurse, system and quality patient care outcomes in 8-hour and 12-hour shifts. Med. Care 44, 1099-1106. doi: 10.1097/01.mlr. 0000237180.72275 .82

Strandas, M., Wackerhausen, S., and Bondas, T. (2019). The nurse-patient relationship in the New Public Management era, in public home care: a focused ethnography. J. Adv. Nurs. 75, 400-411. doi: 10.1111/jan.13850

Suliman, A. M., and Al-Shaikh, F. N. (2007). Emotional intelligence at work: links to conflict and innovation. Employee Relat. 29, 208-220. doi: 10.1108/ 01425450710720020

Surina, S., Martinsone, K., Perepjolkina, V., Kolesnikova, J., Vainik, U., Ruza, A., et al. (2021). Factors related to COVID-19 preventive behaviors: a structural equation model. Front. Psychol. 12:676521. doi: 10.3389/fpsyg.2021.676521

Swift, P. E., and Hwang, A. (2013). The impact of affective and cognitive trust on knowledge sharing and organizational learning. Learn. Organ. 20, 20-37. doi: 10.1108/09696471311288500

Syed, J., Ali, F., and Winstanley, D. (2005). In pursuit of modesty: contextual emotional labour and the dilemma for working women in Islamic societies. Int. J. Work Organ. Emot. 1, 150-167. doi: 10.1504/IJWOE.2005.008819

Szmulewitz, A. G., Benson, M. N., Hsu, J., Hernan, M. A., and Ongur, D. (2021). Effects of COVID-19 pandemic on mental health outcomes in a cohort of early psychosis patients. Early Interv. Psychiatry 15, 1799-1802. doi: 10.1111/eip. 13113

Tang, Q., and Luo, L. (2016). Corporate ecological transparency: theories and empirical evidence. Asian Rev. Account. 24, 498-524. doi: 10.1108/ARA-012015-0007

Taylor, S., Palusek, M. M., Rachor, G. S., McKay, D., and Asmudson, J. G. J. (2021). Substance use and abuse, COVID-19-related distress, and disregard for social distancing: a network analysis. Addidive Behav. 114:106754. doi: 10.1016/ j.addbeh.2020.106754

Thaler, R. H., and Sunstein, C. R. (2008). Nudge: Improving Decisions About Health, Wealth, and Happiness. New Haven, CT: Yale University Press.

Thomson, K., and Hecker, L. (2001). Value-adding communication: innovation in employee communication and internal marketing. J. Commun. Manag. 5, 48-58. doi: $10.1108 / 13632540110806668$

Thorpe, R., Holt, R., Clarke, J., and Gold, J. (2006). Immaturity: the constraining of entrepreneurship. Int. Small Bus. J. 24, 232-252. doi: 10.1177/ 0266242606063431

Tiberius, V., and Hauptmeijer, R. (2021). Equity crowdfunding: forecasting market development, platform evolution, and regulation. J. Small Bus. Manag. 59, 337-369. doi: 10.1080/00472778.2020.1849714

Tolochko, S., Bordyug, N., and Knysh, I. (2020). Transversal competencies of innovative entrepreneurship professionals in lifelong education. Baltic J. Econ. Stud. 6, 156-165. doi: 10.30525/2256-0742/2020-6-3-156-165

Tsunoda, A., Nakao, K., Hiratsuda, K., Tsunoda, Y., and Kusano, M. (2007). Prospective analysis of quality of life in the first year after colorectal cancer surgery. Acta Oncol. 46, 77-82. doi: 10.1080/0284186060084 7053

Tuber, L. (2019). Beyond homogeneity: redefining social entrepreneurship in authoritarian context. J. Soc. Entrep. 12, 50-68. doi: 10.1080/19420676.2019. 1668829 
Tuck, I., and Wallace, D. C. (2000). Exploring parish nursing from an ethnographic perspective. J. Transcult. Nurs. 11, 290-299. doi: 10.1177/104365960001100407

Valaskakis, K. (1987). Should the gorging leviathan become anorexic? Can. J. Adm. Sci. Revue Can. Sci. l'Adm. 4, 381-409. doi: 10.1111/j.1936-4490.1987.tb00005.x

Verkerk, M. J. (2013). Social entrepreneurship and impact investing. Philos. Reformata 78, 209-221. doi: 10.1163/22116117-90000553

Vinall-Collier, K., Madill, A., and Firth, J. (2016). A multi-centre study of interactional style in nurse specialist- and physician-led Rheumatology clinics in the UK. Int. J. Nurs. Stud. 59, 41-50. doi: 10.1016/j.ijnurstu.2016.02.009

Vorhauser-Smith, S. (2011). Integrate neuroscience into work-based learning programs: designing programs based on scientific theory. Dev. Learn. Organ. 24, 13-16. doi: 10.1108/14777281111159384

Waddington, L., and Fletcher, C. (2005). Gossip and emotion in nursing and health-care organizations. J. Health Organ. Manag. 19, 378-394. doi: 10.1108/ 14777260510615404

Waltman, L., Van Eck, V. J., and Noyons, E. C. M. (2010). A unified approach to mapping and clustering of bibliometric networks. J. Infometrics 4, 629-635.

Wei, H., and Li, S. (2011). Confucian nurturing doctrine of xin (heart-mind): its enlightenment to organization research. J. Manag. Dev. 30, 753-765. doi: $10.1108 / 02621711111150254$

Wempe, B. (2008). Understanding the separation thesis: precision after the decimal point? A response to Joakim Sandberg. Bus. Ethic Q. 18, 549-553.

Werhane, P. H., and Freeman, R. E. (1999). Business ethic: the state of art. Int. J. Manag. Rev. 1, 1-16. doi: 10.1111/1468-2370.00002

Wilkinson, H. (2002). Editorial: pluralism and the basis of freewill in psychotherapy. Int. J. Psychother. 7, 181-184. doi: 10.1080/ 1356908021000067147

Wolff, H. G., and Kim, S. (2012). The relationship between networking behaviors and the Big Five personality dimensions. Career Dev. Int. 17, 43-56. doi: 10. $1108 / 13620431211201328$

Worthington, R. (2012). Prison organisational climate: exploring the impact of climate on emotional well being. Br. J. Forensic Pract. 14, 192-203. doi: 10.1108/ 14636641211254914

Wright, M., and Baker, A. (2005). The effects of appreciative inquiry interviews on staff in the UK National Health Service. Int. J. Health Care Qual. Assur. 18, 41-61. doi: 10.1108/09526860510576965

Wu, Y., Zhang, Y., and Zou, L. (2020). Effects of anxiety, depression, and fatigue on quality of life in early esophageal cancer patients following endoscopic submucosal dissection. Ann. Palliative Med. 9, 3766-3775. doi: 10.21037/apm20-1632

Wynes, M. J. (2021). Anger, fear, and investor's information search behavior. J. Behav. Finance 22, 403-419. doi: 10.1080/15427560.2020.178 6386

Yagil, D. (2014). Trust in the supervisor and authenticity in service roles. J. Serv. Manag. 25, 411-426. doi: 10.1108/JOSM-09-2012-0199

Yang, Y. (2016). Comparative study of emotional value perception, communication and political support in online environment. Procedia Comput. Sci. 91, 11301137. doi: 10.1016/j.procs.2016.07.167
Yanishev-Nesterova, I. (2020). Soviet big business: the rise and fall of the state corporation Soryblflot, 1965-1991. Bus. History 1-24.

Ye, B. J., Zeng, Y. D., Im, H. J., Liu, M. F., Wang, J. D., and Yang, Q. (2021). The relationship between fear of COVID-19 and online aggressive behavior: a moderated mediation model. Front. Psychol. 12:589615. doi: 10.3389/fpsyg. 2021.589615

Yip, B., and Rowlinson, S. (2009). Job burnout among construction engineers working within consulting and contracting organizations. J. Manag. Eng. 25, 122-130. doi: 10.1061/(ASCE)0742-597X200925:3(122)

Young, M., and Dulewitz, V. (2007). Relationships between emotional and congruent self-awareness and performance in the British Royal Navy. J. Manag. Psychol. 22, 465-478. doi: 10.1108/02683940710757191

Yu, D. S. F., Lee, D. T. F., and Wu, J. (2010). Improving health-related quality of life of patients with chronic heart failure: effects of relaxation therapy. J. Adv. Nurs. 66, 392-403. doi: 10.1111/j.1365-2648.2009.05198.x

Yu, P., Lu, X. B., Chen, Y. Y., Ye, H., Zng, L. L., and Guo, W. M. (2021). Modulating OFC activity with tDCS alters regret about human decision-making. Front. Psychol. 12:706962. doi: 10.3389/fpsyg.2021.706962

Zang, D., Hu, M., and Li, Q. (2020). Financial markets under the global pandemic of COVID-19. Finance Res. Lett. 2020:101528.

Zarinah, A. R., Farhana, A. N. M., and Nadiah, A. H. (2017). Lean production and business performance: influences of leadership styles. J. Fundam. Appl. Sci. 9, 1030-1051. doi: 10.4314/jfas.v9i5s.71

Zhang, S., and Shi, Q. (2017). The relationship between subjective well-being and workplace ostracism: the moderating role of emotional intelligence. J. Organ. Change Manag. 30, 978-988. doi: 10.1108/JOCM-07-2016-0139

Zhang, Y., Tian, L., Li, W., Wen, X., Wu, H., Gong, R., et al. (2021). Mental health status among Chinese healthcare-associated infection control professionals during the outbreak of coronavirus disease 2019: a national cross-sectional survey. Medicine 100:e24503. doi: 10.1097/MD.0000000000024503

Conflict of Interest: The authors declare that the research was conducted in the absence of any commercial or financial relationships that could be construed as a potential conflict of interest.

Publisher's Note: All claims expressed in this article are solely those of the authors and do not necessarily represent those of their affiliated organizations, or those of the publisher, the editors and the reviewers. Any product that may be evaluated in this article, or claim that may be made by its manufacturer, is not guaranteed or endorsed by the publisher.

Copyright @ 2022 Pascucci, Cardella, Hernández-Sánchez and Sánchez-García. This is an open-access article distributed under the terms of the Creative Commons Attribution License (CC BY). The use, distribution or reproduction in other forums is permitted, provided the original author $(s)$ and the copyright owner(s) are credited and that the original publication in this journal is cited, in accordance with accepted academic practice. No use, distribution or reproduction is permitted which does not comply with these terms. 